\title{
Alleged tax competition: The mysterious death of bequest taxes in Switzerland ${ }^{\text {tr }}$
}

\author{
Marius Brülhart a,b,*, Raphaël Parchet ${ }^{c}$ \\ a Faculty of Business and Economics (HEC Lausanne), University of Lausanne, 1015 Lausanne, Switzerland \\ b Center for Economic Policy Research, London, United Kingdom \\ c Institute for Economic Research, University of Lugano, 6900 Lugano, Switzerland
}

\section{A R T I C L E I N F O}

\section{Article history:}

Received 8 June 2010

Received in revised form 17 December 2013

Accepted 22 December 2013

Available online 13 January 2014

\section{JEL classification:}

H3

H7

\section{Keywords:}

Tax competition

Bequest taxation

Fiscal federalism

\begin{abstract}
A B S T R A C T
Interjurisdictional competition over mobile tax bases is an easily understood mechanism, but actual tax-base elasticities are difficult to estimate. Political pressure for reducing tax rates could therefore be based on erroneous estimates of the mobility of tax bases. We show that tax competition provided the most prominent argument in the policy debates leading to a succession of reforms of bequest taxation by Swiss cantons. Yet, canton-level panel data spanning multiple bequest tax reforms over a 36-year period suggest the relevant tax base, high-income retirees, to be relatively inelastic with respect to tax rates. The alleged pressures of tax competition did not seem in reality to exist.
\end{abstract}

(c) 2014 Elsevier B.V. All rights reserved.

\section{Introduction}

Governments, it is often argued, are finding it increasingly difficult to raise revenue, as people and capital are becoming ever more mobile. This would mean that tax bases are increasingly elastic, and that revenue-maximising as well as welfare-maximising tax rates are falling. The logic and relevance of this tax competition mechanism are not in doubt, underpinned as they are by large bodies of theoretical and empirical research. ${ }^{1}$

Existing research does not, however, address a potential corollary of this fiscal phenomenon. While the conceptual logic of tax competition is simple, the practical estimation of tax-base elasticities and optimal tax

\footnotetext{
We thank the editor (James Hines), two anonymous referees, and seminar participants at the CEPR Public Policy Symposium in Lugano, at IHS Vienna, WZB Berlin, IEB Barcelona, CEU Budapest, and at the Universities of Lausanne and Paris 1 for their helpful suggestions. Hansueli Bacher provided valuable help with the data. Financial support from the Swiss National Science foundation (Sinergia grants 130648 and 147668, NCCR "Trade Regulation", and ProDoc grant 123133) and from the EU's Sixth Framework Programme ("Micro-Dyn" project) is gratefully acknowledged. We are particularly indebted to Roger Ammann, Kurt Duetschler and Bruno Jeitziner at the Swiss Federal Tax Administration for granting us access to individual-level federal tax data; and to Claude Enz at the Vaud cantonal statistics office for granting us access to bequest data.

* Corresponding author.

E-mail addresses: marius.brulhart@unil.ch (M. Brülhart), raphael.parchet@usi.ch (R. Parchet).

${ }^{1}$ For overviews of the theory, see e.g. Wilson (1999) and Haufler (2001). Empirical evidence on international tax competition is provided e.g. by Griffith and Klemm (2004) and by Hines (2007).
}

rates is fraught with uncertainty. When tax competition becomes a dominant theme in policy debates, policy could overshoot by lowering tax rates beyond what would be the optimal response to changing tax-base elasticities. This may be called "alleged tax competition": political pressure for reducing certain tax rates that is based on upward biased estimates of the inter-jurisdictional mobility of the concerned tax bases. ${ }^{2}$

We study the case of bequest taxation in Switzerland, where the relevant tax base is constitutionally assigned to sub-federal governments (cantons). Bequest taxes have been repealed or significantly lowered by a majority of cantons in a domino-like process that began in the late 1980s. We document that the first and by far the most important argument invoked by the (almost always successful) proponents of reform was tax competition: with wealthy taxpayers becoming increasingly footloose, they argued, tax burdens had to be lowered in order to retain the tax base and, possibly, to expand it. In this sense, recent Swiss policy changes mirror a broader trend. Over the last three decades, more than 30 US states have eliminated their bequest taxes - a development which Conway and Rork (2004) considered "a prime example of intense interstate tax competition". ${ }^{3}$ The same

\footnotetext{
2 The opposite scenario, whereby taxes are insufficiently responsive to changes in the mobility of tax bases, is of course conceivable as well.

${ }^{3}$ In subsequent work, however, the same authors detected no statistically significant evidence of a link between bequest tax burdens and migration flows of elderly residents (Conway and Rork, 2006, 2012).
} 
logic is invoked at the international level. When Hong Kong abolished its estate tax in 2005, the government's official justification was that "a number of countries in the region, including India, Malaysia, New Zealand and Australia, have abolished estate duty over the past 20 years. Hong Kong must not lose out in this race". ${ }^{4}$ In 2008, Singapore followed suit, in order to "encourage wealthy individuals from all over Asia to bring their assets into Singapore". ${ }^{5}$

The erosion of bequest taxes, however, is not a universal phenomenon. As can be gleaned from Table 1, the share of bequest tax revenues in total tax revenues decreased in 20 OECD countries but increased in 12 other OECD countries over the period 1995 to 2010. Table 1 also suggests that the contraction of bequest tax revenues has not been stronger in countries with some degree of sub-federal bequest taxation than in countries where bequests are taxed solely by the federal government. Given this variety of policy choices, research on the elasticity of the bequest tax base appears particularly relevant.

We explore this issue in panel data for Swiss cantons spanning four decades. Using a range of econometric specifications, we fail to uncover a statistically significant within-sample relationship between bequest tax rates and the relevant tax base, high-income elderly individuals. The alleged pressures for tax reforms due to mobile tax bases therefore are not apparent in the available data.

Our work is related to a number of previous studies. First, several researchers have estimated tax-base elasticities with respect to bequest taxation in the United States. Bakija and Slemrod (2004) find that state bequest taxes have a statistically significant negative effect on the number of federal estate tax returns filed in a state, inferred from stratified samples. The estimated effects, however, are economically small, in the sense that they are well below the elasticities that would imply a potential for revenue-raising tax cuts. A similar verdict emerges from the work of Conway and Rork (2006, 2012), who find no statistical evidence that bequest taxes (nor indeed any other fiscal measures targeted at the elderly) affect inter-state migration patterns of elderly Americans.

Could it be that the United States is too large, and/or intra-national variation of tax rates too limited, for significant mobility responses to differences in bequest taxation? Data on Switzerland allow us to examine this question in a much smaller country with somewhat heavier and more heterogeneous sub-federal bequest taxation. Our study differs from US-based analyses in two additional respects: we can formally document the weight of the tax competition argument in tax-setting policy decisions, and we have access to data on local changes in federal income tax revenues from the full population of taxpayers.

A second related literature investigates strategic interactions in bequest tax setting at the sub-national level. ${ }^{6}$ Conway and Rork (2004) have estimated reaction functions among US state-level estate tax rates. They find evidence of correlated changes in tax rates among states with large inter-state migration flows of elderly residents. They interpret this as evidence of inter-state tax competition. It is, however, difficult to infer competition over mobile tax bases from tax reaction functions. Spatially correlated tax changes could be a manifestation of other types of policy interactions or of correlated unobservables (see, e.g., Brueckner, 2003). One way of identifying the presence of competition over mobile tax bases is by estimating the mobility of tax bases directly (Brett and Pinkse, 2000; Buettner, 2003; Bakija and Slemrod, 2004; Conway and Rork, 2006, 2012). This will be the central focus of our study, which aims to estimate the effect of changes in estate tax rates on inter-jurisdictional movements of the most directly concerned tax bases.

\footnotetext{
${ }^{4}$ www.lowtax.net/lowtax/html/hongkong/jhkpetx.html\#estate.

5 www.prlog.org/10051481-singapore-abolished-estate-duty-tax-with-immediateeffects.html.

6 On the economic and political forces behind the erosion of bequest tax rates, see Gale and Slemrod (2001) and Graez and Shapiro (2005) for the US, and Bertocchi (2011) for a theoretical explanation. On the broader question of the optimal level of bequest taxation, see Cremer and Pestieau (2006), Kopczuk (2010), and Piketty and Saez (2013).
}

The paper is structured as follows. In Section 2, we describe bequest taxation and fiscal policy making in Switzerland, we document the erosion of bequest taxes, and we quantify the dominance of the tax competition argument in the associated policy debates. We set out our empirical strategy and data in Section 3. In Section 4, we report our estimates of behavioural responses to changes in bequest tax rates. We conclude by summarising and discussing our findings in Section 5.

\section{Bequest taxation in Switzerland}

\subsection{Decentralisation and reforms}

The Swiss political system features a high degree of fiscal decentralisation and considerable variability in tax burdens across sub-federal jurisdictions. This makes Switzerland a well suited empirical testing ground for questions related to tax competition. ${ }^{7}$

Bequest taxation is a case in point. It is constitutionally assigned exclusively to the 26 cantons, and cantonal bequest tax codes differ substantially. ${ }^{8}$ Bequest taxes on assets other than real estate are due by the heirs to the canton in which the deceased had their last fiscal residence. Like in most countries, including the United States, the transfer of real estate, representing around one third of the value of bequests, is taxed in the jurisdiction in which the property is located.

25 of the 26 cantons levy bequest taxes (the exception being the canton of Schwyz). In 23 of those 25 cantons, bequest taxes were introduced between 1884 and 1918, the remaining two cantons, Valais and Obwalden, taking that step in 1977 and 1981, respectively. In most cases, bequest taxes are levied on inheritances, such that tax rates vary in two main dimensions: the amount inherited (progressive taxation) and family ties with the deceased (the closer the ties, the lower the tax rate). ${ }^{9}$ On average, spouses and direct descendants represent some three quarters of all heirs.

In our sample of tax data, which spans the period 1973 to 2008, the highest average tax rate for spouses and direct descendants is $9 \%$, whereas unrelated heirs have been taxed in some cantons at up to $60 \%$. Table 1 shows that bequest taxation weighed more heavily as a share of total tax revenue in Switzerland than in most other OECD countries. In 1995, for instance, Swiss bequest taxes accounted for some $1.8 \%$ of consolidated tax revenues, significantly more than in the United States (1.3\%), and three times the OECD average of $0.6 \%{ }^{10}$

Of the cantons that have at some point within our sample period levied bequest taxes on direct descendants and/or spouses, the timeaveraged representative tax rate is around five times higher in the highest-tax canton than in the canton with the lowest (non-zero) rate. These differences, however, have narrowed significantly in recent years. A wave of canton-level reforms has been implemented since the late 1980s with the result of markedly lowering bequest tax burdens across the country. Of the 17 cantons that had imposed an inheritance tax on direct descendants and/or spouses in 1973, only three still applied a tax on direct descendants in 2008, and none taxed inheritances by spouses. This is illustrated in Fig. 1, which shows the evolution of the average bequest tax rate in each of the 26 cantons. ${ }^{11}$ Table 2 provides details on the 32 largest reforms. 29 of these reforms implied cuts in the average bequest tax rate, with reductions in representative

\footnotetext{
${ }^{7}$ For additional detail on Swiss sub-federal taxation, see Brülhart and Jametti (2006).

8 In four cantons (Fribourg, Graubünden, Luzern and Vaud), municipalities can in addition levy their own bequest taxes.

${ }^{9}$ Estate taxation is or has been applied in three cantons (see Section A.2 in the Appendix A).

${ }^{10}$ Despite generally lower top marginal tax rates, the share of bequest tax revenues in total tax revenues has been higher in Switzerland than in the United States since the early 1980s. This is likely explained by greater wealth concentration in Switzerland and comparatively low exemption levels.

${ }^{11}$ Details on how we calculate average bequest tax rates are given in Section 3.4 and the Appendix A.
} 
Table 1

Bequest taxation across OECD countries; 1975, 1995 and 2010.

\begin{tabular}{|c|c|c|c|c|c|c|}
\hline & \multicolumn{3}{|c|}{ Share of bequest taxes in total tax revenue (\%) } & \multicolumn{3}{|c|}{$\begin{array}{l}\text { Share of federal-government bequest taxes in total } \\
\text { bequest tax revenue (\%) }\end{array}$} \\
\hline & 1975 & 1995 & 2010 & 1975 & 1995 & 2010 \\
\hline \multicolumn{7}{|c|}{$\begin{array}{l}\text { (A) Countries with sub-federal bequest taxation } \\
\text { (A.1) Countries with data from } 1975\end{array}$} \\
\hline Australia & 1.487 & 0.000 & 0.000 & 27.7 & n.a. & n.a. \\
\hline Austria & 0.247 & 0.160 & 0.041 & 70.6 & 100.0 & 100.0 \\
\hline Belgium & 1.095 & 1.144 & 2.220 & 100.0 & 6.1 & 0.0 \\
\hline Canada & 0.301 & 0.001 & 0.000 & 8.3 & 0.0 & n.a. \\
\hline Germany & 0.221 & 0.436 & 0.809 & 0.0 & 0.0 & 0.0 \\
\hline Italy & 0.384 & 0.227 & 0.106 & 100.0 & 100.0 & 93.4 \\
\hline Spain & 1.504 & 0.956 & 1.204 & 100.0 & 0.1 & 3.8 \\
\hline Switzerland & 1.032 & 1.820 & 1.185 & 0.0 & 0.0 & 0.0 \\
\hline United States & 1.825 & 1.304 & 0.730 & 76.5 & 74.6 & 76.8 \\
\hline Unweighted mean & 0.900 & 0.672 & 0.700 & 53.7 & 35.1 & 39.1 \\
\hline \multicolumn{7}{|c|}{ (A.2) countries with data from 1995} \\
\hline Hungary & & 0.173 & 0.089 & & 50.0 & 56.2 \\
\hline Mexico & & 0.001 & 0.000 & & 0.0 & n.a. \\
\hline Poland & & 0.057 & 0.100 & & 0.0 & 0.0 \\
\hline Slovenia & & 0.043 & 0.176 & & 0.0 & 0.0 \\
\hline Turkey & & 0.072 & 0.112 & & 100.0 & 89.3 \\
\hline Unweighted mean & & 0.069 & 0.095 & & 30.0 & 36.4 \\
\hline \multicolumn{7}{|c|}{$\begin{array}{l}\text { (B) Countries with federal-level bequest taxation only } \\
\text { (B.1) Countries with data from } 1975\end{array}$} \\
\hline Denmark & 0.391 & 0.487 & 0.463 & 100 & 100 & 100 \\
\hline Finland & 0.267 & 0.553 & 0.727 & 100 & 100 & 100 \\
\hline France & 1.269 & 1.547 & 2.037 & 100 & 100 & 100 \\
\hline Greece & 0.996 & 0.972 & 0.232 & 100 & 100 & 100 \\
\hline Iceland & 0.000 & 0.275 & 0.484 & n.a. & 100 & 100 \\
\hline Ireland & 1.323 & 0.514 & 0.654 & 100 & 100 & 100 \\
\hline Japan & 1.368 & 3.035 & 1.602 & 100 & 100 & 100 \\
\hline Korea & 0.709 & 1.427 & 1.356 & 100 & 100 & 100 \\
\hline Luxemburg & 0.462 & 0.364 & 0.468 & 100 & 100 & 100 \\
\hline Netherlands & 0.623 & 1.069 & 1.201 & 100 & 100 & 100 \\
\hline New Zealand & 1.564 & 0.009 & 0.003 & 100 & 100 & 100 \\
\hline Norway & 0.300 & 0.324 & 0.220 & 100 & 100 & 100 \\
\hline Portugal & 1.316 & 0.285 & 0.215 & 100 & 100 & 100 \\
\hline Sweden & 0.315 & 0.207 & 0.001 & 100 & 100 & 100 \\
\hline United Kingdom & 1.008 & 0.711 & 0.643 & 100 & 100 & 100 \\
\hline Unweighted mean & 0.794 & 0.785 & 0.687 & 100 & 100 & 100 \\
\hline \multicolumn{7}{|c|}{ (B.2) Countries with data from 1995} \\
\hline Chile & & 0.255 & 0.191 & & 100 & 100 \\
\hline Czech Republic & & 0.122 & 0.031 & & 100 & 100 \\
\hline Slovakia & & 0.040 & 0.000 & & 100 & n.a. \\
\hline Unweighted mean & & 0.139 & 0.074 & & 100 & 100 \\
\hline \multicolumn{7}{|l|}{ (C) Overall unweighted means } \\
\hline All countries & & 0.581 & 0.541 & & 72.0 & 75.7 \\
\hline Countries with data from 1975 & 0.834 & 0.743 & 0.692 & 81.9 & 77.4 & 80.6 \\
\hline
\end{tabular}

Source: OECD Revenue Statistics 2012, tax revenues by subsectors of general government.

rates ranging from 5.5 to $71.7 \%$. It is this wave of reforms that will provide the main identifying variation for our estimations.

\subsection{The tax competition argument}

All major reforms to cantonal bequest taxation were preceded by vigorous public debate, and in 16 cases they were passed through referenda. One advantage of the broad based (direct) democratic decisionmaking procedures in Swiss cantons is that they offer us comparable official documents laying out the arguments that dominated political discussions. We have analysed official voting brochures for reforms in 15 cantons, selected to include a maximum number of referenda as well as all reforms that implied a decrease in the average bequest tax rate of more than $25 \%{ }^{12}$

\footnotetext{
12 For three referenda, Zürich in 1986, Appenzell Ausserrhoden in 1992 and Nidwalden in 1994, we did not have access to official documents. No pro-reform argument was presented in Aargau in 1999. Table 2 lists the 15 reforms analysed (see column "Prevalence of tax competition arguments").
}

Official brochures are issued routinely by cantonal governments to accompany public and parliamentary votes, laying out the arguments of the executive. In all of the 15 referenda for which we have official brochures, cantonal governments advocated adoption of the reforms. In order to quantify the relative weights of the arguments made, we counted the number of words dedicated to each pro-reform argument, and we recorded their order of appearance.

Results are presented in Fig. 2. It is easy to see that tax competition was by far the most prominent argument, both in terms of the space dedicated to it and in terms of the order in which the arguments were made. The tax competition argument appears almost exclusively in first position and accounts for some $64 \%$ of text space, far ahead of alternative arguments for tax reform, such as the fact that taxing bequests can be considered a form of multiple taxation (16\%), that it might impede the transfer of family-owned firms (8\%), or that it may be viewed as infringing private property rights (6\%).

If inter-cantonal mobility of high-income elderly residents has been presented as the central argument in favour of reducing tax rates, avoidance strategies other than mobility could theoretically also be at play. 


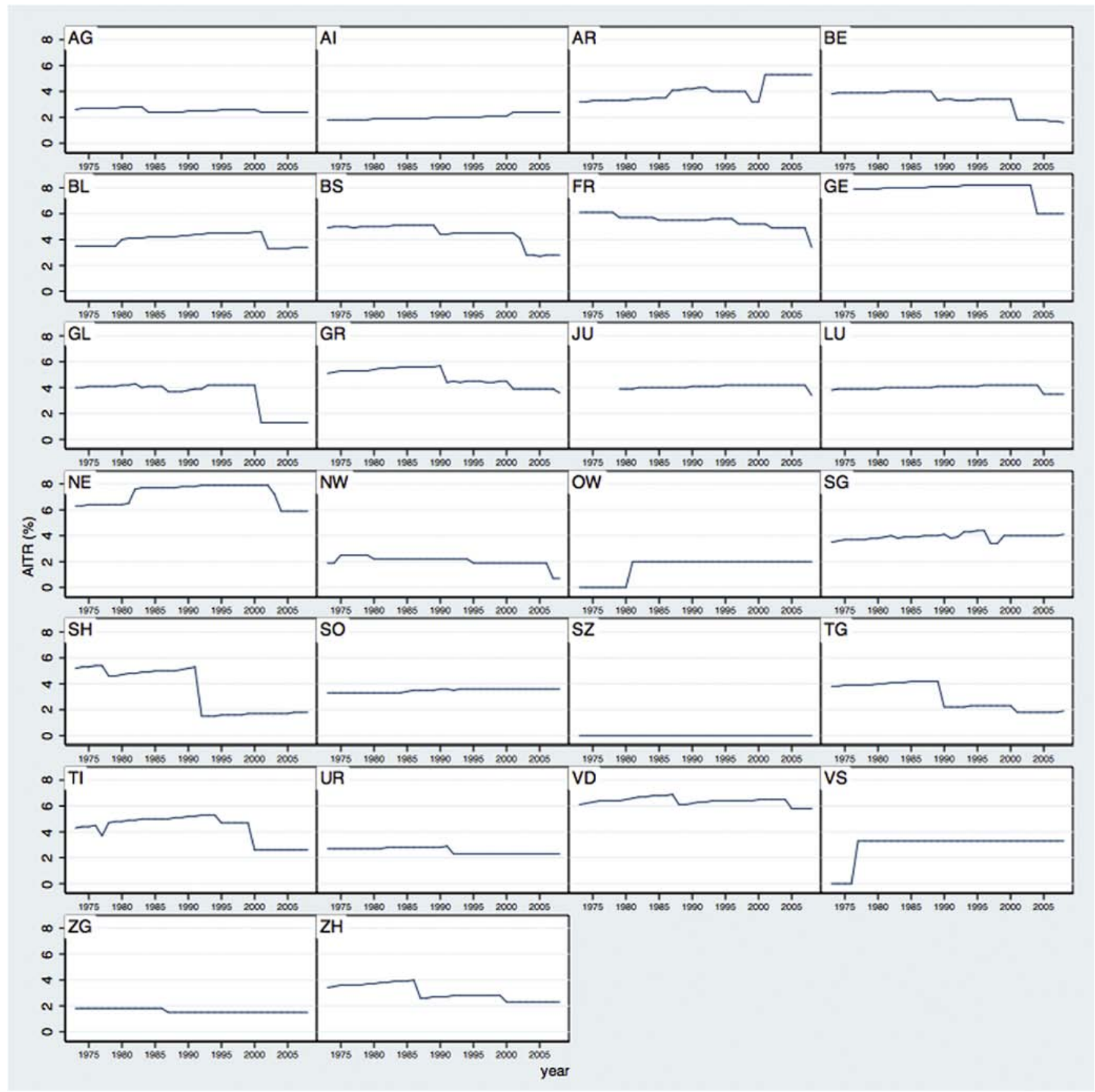

Note: The average inheritance tax rate (AITR) is defined in the Appendix. For full canton names, see Table 2.

Fig. 1. Average inheritance tax rate by canton, 1973-2008.

Gifts, property investments in lower-tax cantons or tax evasion are potential alternative responses to tax differentials. By estimating the effects of bequest tax reforms on federal income-tax revenues from elderly taxpayers, we will be able to assess the fiscal impact of such reforms in the face of other conceivable avoidance strategies. ${ }^{13}$

\footnotetext{
13 Behavioural responses in the form of evasion are conceivable but rather implausible explanation given the tight legal controls over estate transfers. Gifts inter vivos offer only limited shelter from inheritance taxation, since they are taxed according to the same schedule as bequests. Endogenous discretionary valuations by tax authorities, however, are conceivable: illiquid assets might be valued more leniently when applicable tax rates are high. If so, the behavioural response would occur on the side of tax authorities rather than on the side of taxpayers.
}

\section{Empirical strategy}

\subsection{Tax rates, mobile tax bases, and tax revenue}

We seek to assess the validity of the tax competition rationale by exploring the extent to which the affected tax base reacted to changes in the bequest tax rate. An extreme version of the tax competition argument is that tax cuts "pay for themselves", in the sense that the elasticity of the tax base equals or exceeds unity. Since this scenario implies Pareto suboptimal tax rates prior to the cuts, it is not an equilibrium outcome in models featuring rational and well-informed agents. However, our document analysis of government brochures shows that such predictions 
Table 2

Major bequest tax reforms.

\begin{tabular}{|c|c|c|c|c|c|c|c|c|c|c|}
\hline \multirow[t]{2}{*}{ Canton } & & \multirow[t]{2}{*}{ Year } & \multirow[t]{2}{*}{ Change } & \multirow[t]{2}{*}{ Main object of reform } & \multirow[t]{2}{*}{ Procedure } & \multirow[t]{2}{*}{ Decision date } & \multirow[t]{2}{*}{ Entry into force } & \multirow{2}{*}{$\begin{array}{l}\text { Prevalence of tax } \\
\text { comp. arguments }\end{array}$} & \multicolumn{2}{|l|}{ AITR } \\
\hline & & & & & & & & & 1973 & 2008 \\
\hline \multicolumn{11}{|l|}{ Cantons with major reforms } \\
\hline Aargau & $(\mathrm{AG})$ & 2001 & $-7.7 \%$ & Repeal tax on direct descendants & Referendum & 18.04.1999 & 01.01 .2001 & & 2.6 & 2.4 \\
\hline \multirow[t]{3}{*}{ Appenzell Ausserrhoden } & $(\mathrm{AR})$ & 1993 & $-7.0 \%$ & Repeal tax on spouses & Referendum ${ }^{\mathrm{a}}$ & 26.04 .1992 & 01.01 .1993 & & 3.2 & 5.3 \\
\hline & & 1999 & $-20.0 \%$ & Repeal tax on direct descendants & Parliamentary vote & 27.09 .1998 & 01.01.1999 & & & \\
\hline & & 2001 & $+65.6 \%$ & Change tax rate & Parliamentary vote & 21.05 .2000 & 01.01 .2001 & & & \\
\hline Basel-Landschaft & $(\mathrm{BL})$ & 2001 & $-28.2 \%$ & Repeal tax on direct descendants & Referendum & 04.03 .2001 & 05.03.2001 & $21 \%$ & 3.5 & 3.4 \\
\hline \multirow[t]{2}{*}{ Basel-Stadt } & (BS) & 1990 & $-13.7 \%$ & Repeal tax on spouses & Parliamentary vote & 16.03 .1989 & 01.01 .1990 & & 4.9 & 2.8 \\
\hline & & 2003 & $-31.7 \%$ & Repeal tax on direct descendants & Referendum & 09.02 .2003 & 10.02 .2003 & $61 \%$ & & \\
\hline \multirow{3}{*}{ Bern } & $(\mathrm{BE})$ & 1989 & $-17.5 \%$ & Repeal tax on spouses & Parliamentary vote & 01.09 .1988 & 01.01.1989 & & 3.8 & 1.6 \\
\hline & & 2001 & $-47.0 \%$ & Change tax rate & Parliamentary vote & 23.11.1999 & 01.01 .2001 & $79 \%$ & & \\
\hline & & 2006 & $-5.5 \%$ & Repeal tax on direct descendants & Parliamentary vote & 23.11 .2004 & 01.01 .2006 & & & \\
\hline \multirow[t]{2}{*}{ Fribourg } & $(\mathrm{FR})$ & 1997 & $-7.1 \%$ & Repeal tax on spouses & Parliamentary vote & 01.05 .1996 & 01.01.1997 & & 6.1 & 3.4 \\
\hline & & 2008 & $-30.6 \%$ & Change tax rate & Parliamentary vote & 27.09 .2007 & 01.01 .2008 & $94 \%$ & & \\
\hline Geneva & $(\mathrm{GE})$ & 2004 & $-26.8 \%$ & Repeal tax on direct desc. and spouses & Referendum & 08.02 .2004 & 01.06 .2004 & $44 \%$ & 7.3 & 6.0 \\
\hline Glarus & (GL) & 2001 & $-69.0 \%$ & Repeal tax on direct descendants & Referendum $^{\mathrm{a}}$ & 07.05 .2000 & 01.01 .2001 & $74 \%$ & 4.0 & 1.3 \\
\hline \multirow[t]{2}{*}{ Graubünden ${ }^{\mathrm{b}}$} & (GR) & 2001 & $-13.3 \%$ & Repeal tax on spouses & Referendum & 13.06.1999 & 01.01 .2001 & $0 \%$ & 5.1 & 3.6 \\
\hline & & 2008 & $-7.7 \%$ & Repeal tax on direct descendants & Parliamentary vote & 08.08 .2006 & 01.01 .2008 & & & \\
\hline Jura & $(\mathrm{JU})$ & 2007 & $-19.0 \%$ & Repeal tax on direct desc. and spouses & Parliamentary vote & 13.12 .2006 & 01.01 .2007 & & $3.9^{\mathrm{c}}$ & 3.4 \\
\hline \multirow[t]{2}{*}{ Neuchâtel } & $(\mathrm{NE})$ & 1982 & $+16.9 \%$ & Change tax rate & $\mathrm{n} / \mathrm{a}$ & $\mathrm{n} / \mathrm{a}$ & $\mathrm{n} / \mathrm{a}$ & & 6.3 & 5.9 \\
\hline & & 2003 & $-25.3 \%$ & Repeal tax on spouses & Parliamentary vote & 21.05 .2002 & 01.01 .2003 & $100 \%$ & & \\
\hline \multirow[t]{3}{*}{ Nidwalden } & $(\mathrm{NW})$ & 1975 & $+31.6 \%$ & Change tax rate & $\mathrm{n} / \mathrm{a}$ & $\mathrm{n} / \mathrm{a}$ & $\mathrm{n} / \mathrm{a}$ & & 1.9 & 0.7 \\
\hline & & 1995 & $-13.6 \%$ & Repeal tax on direct desc. and spouses & Referendum $^{\mathrm{a}}$ & 24.04 .1994 & 01.01 .1995 & & & \\
\hline & & 2007 & $-63.1 \%$ & Change tax rate & Referendum & 21.05 .2006 & 01.01 .2007 & $100 \%$ & & \\
\hline Schaffhausen & $(\mathrm{SH})$ & 1992 & $-71.7 \%$ & Repeal tax on direct descendants & Referendum & 15.12 .1991 & 16.12 .1991 & $100 \%$ & 5.2 & 1.8 \\
\hline \multirow[t]{2}{*}{ St. Gallen } & (SG) & 1991 & $-7.3 \%$ & Repeal tax on spouses & Parliamentary vote & 09.05 .1990 & 01.01 .1991 & & 3.5 & 4.1 \\
\hline & & 1997 & $-22.7 \%$ & Repeal tax on direct descendants & Referendum & 08.06 .1997 & 09.06.1997 & $76 \%$ & & \\
\hline \multirow[t]{2}{*}{ Thurgau } & (TG) & 1990 & $-47.6 \%$ & Repeal tax on spouses & Referendum & 24.09 .1989 & 01.01 .1990 & $58 \%$ & 3.8 & 1.9 \\
\hline & & 2001 & $-21.7 \%$ & Repeal tax on direct descendants & Parliamentary vote & 24.05 .2000 & 01.01 .2001 & & & \\
\hline \multirow[t]{2}{*}{ Ticino } & $(\mathrm{TI})$ & 1995 & $-11.3 \%$ & Repeal tax on spouses & Parliamentary vote & 21.06 .1994 & 01.01.1995 & & 4.3 & 2.6 \\
\hline & & 2000 & $-44.7 \%$ & Repeal tax on direct descendants & Referendum & 06.02 .2000 & 01.01 .2000 & $60 \%$ & & \\
\hline Vaud & $(\mathrm{VD})$ & 2005 & $-10.8 \%$ & Repeal tax on spouses & Referendum & 16.05 .2004 & 01.01 .2005 & $22 \%$ & 6.1 & 5.8 \\
\hline \multirow[t]{2}{*}{ Zürich } & $(\mathrm{ZH})$ & 1987 & $-35.0 \%$ & Change tax rate & Referendum & 28.09 .1986 & 28.09.1986 & & 3.4 & 2.3 \\
\hline & & 2000 & $-17.9 \%$ & Repeal tax on direct descendants & Referendum & 28.11.1999 & 01.01 .2000 & $77 \%$ & & \\
\hline Cantons that introduced a & bequest & $\operatorname{tax}$ & & & & & & & & \\
\hline Obwalden & (OW) & 1981 & & & $\mathrm{n} / \mathrm{a}$ & 21.10 .1979 & 01.01.1981 & & 0.00 & 2.0 \\
\hline Valais & (VS) & 1977 & & & Parliamentary vote & 10.03.1976 & 01.03.1977 & & 0.00 & 3.3 \\
\hline Cantons with no major re & prms & & & & & & & & & \\
\hline Appenzell Innerrhoden & $(\mathrm{AI})$ & & & & & & & & 1.8 & 2.4 \\
\hline Luzern & $(\mathrm{LU})$ & & & & & & & & 3.8 & 3.5 \\
\hline Schwyz & (SZ) & & & & & & & & 0.0 & 0.0 \\
\hline Solothurn & (SO) & & & & & & & & 3.3 & 3.6 \\
\hline Uri & (UR) & & & & & & & & 2.7 & 2.3 \\
\hline Zug & $(\mathrm{ZG})$ & & & & & & & & 1.8 & 1.5 \\
\hline
\end{tabular}

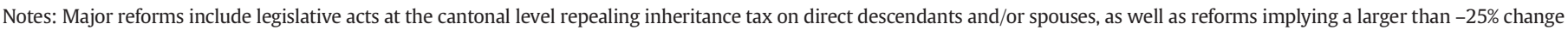

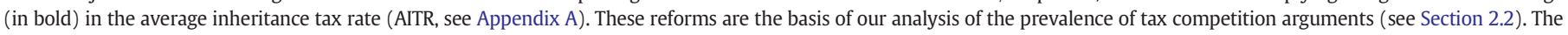

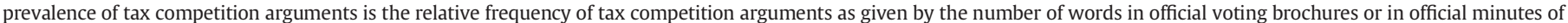
parliamentary debates.

a Citizen assembly.

b The canton of Graubünden levies an estate tax.

c Data for 1979, when the canton of Jura was created by separating from the canton of Bern.

featured prominently among the arguments made by advocates of bequest tax reforms.

According to a second version of the tax competition argument, bequest tax revenues themselves may fall with a tax cut but overall tax revenues will rise, as lower bequest taxes attract high-income individuals who pay taxes also during their lifetime. We are able to explore this prediction by estimating the effect of bequest tax rates on canton-level revenues generated by the federal income tax on retirees overall, and on high-income retirees specifically. The federal income tax schedule being more progressive than cantonal income tax schedules, this measure will be particularly sensitive to behavioural responses by the members of the upper reaches of the retiree income distribution.

Tax competition may also lead a jurisdiction to follow suit on other jurisdictions' tax cuts even if this response were not in fact to yield higher revenues, be it from the affected tax base itself or from all tax bases taken together. Two-region Nash equilibria with tax rates as governments' strategic variable imply that tax rates are strategic complements (Wildasin, 1991). According to the logic of such a model, an exogenously determined tax cut in one region will trigger cuts by the other jurisdictions, even if everybody will end up worse off in terms of revenue. However, local tax rates may well be strategic substitutes if local governments compete over expenditure levels (Wildasin, 1991; Koethenbuerger, 2011) or if the public and the private goods are close complements (de Mooij and Vrijburg, 2012), a conjecture that is supported empirically with data for Switzerland in Parchet (2013). In such a competitive setting, it is difficult to rationalise the observed wave of canton-level tax reforms as a series of optimal responses.

An indirect way of gauging the relevance of tax-induced mobility, and thus of tax competition, is to consider size differences of jurisdictions. In the standard tax competition model, the elasticity of the tax base with respect to the tax rate is negative, but it is less strongly 


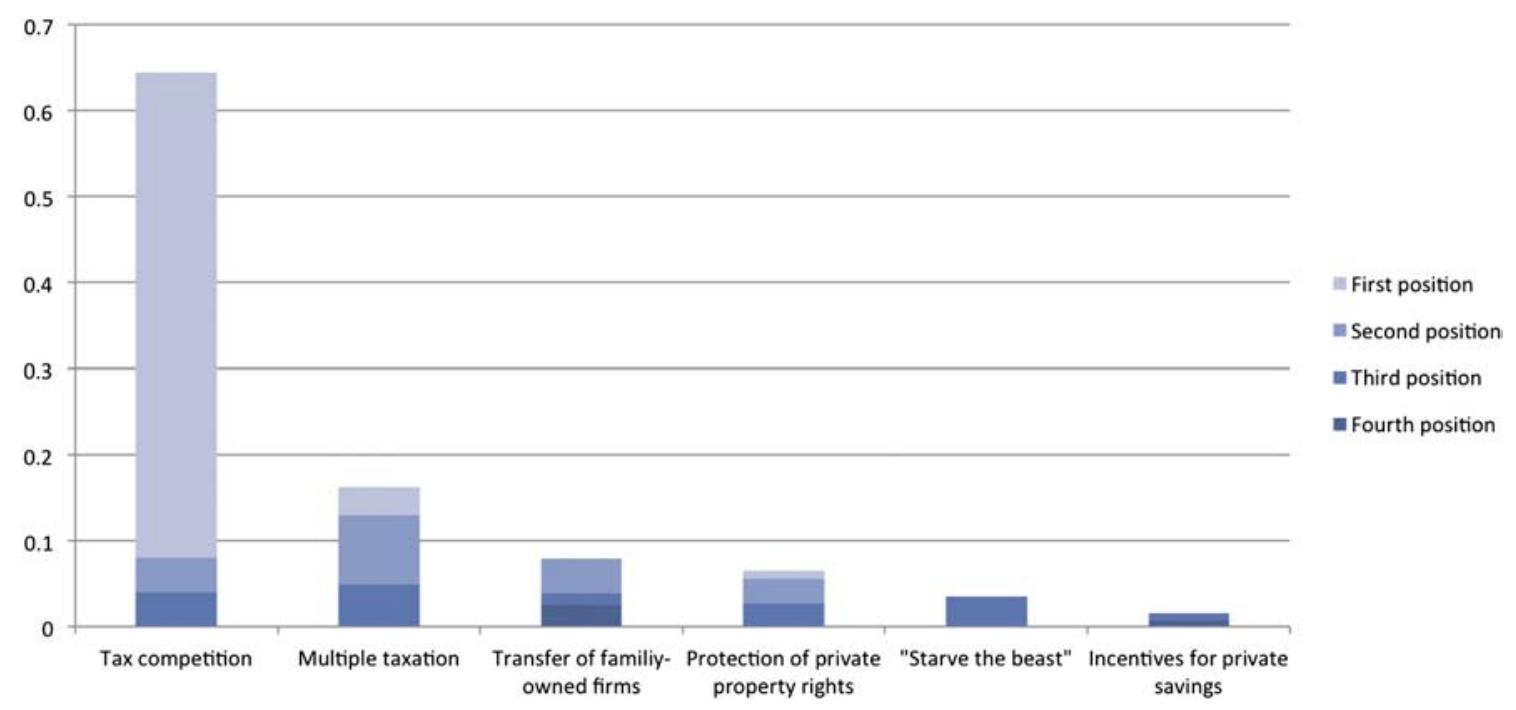

Note: Each bar shows the average over the 15 most important reforms of the relative frequencies of each class of pro-reform argument as given by the number of words. Bars show the order of appearance of each argument. Reforms are listed in Table 2.

Fig. 2. Relative weight and rank of main arguments in favour of bequest tax reforms.

negative in large jurisdictions than in small jurisdictions (see e.g. Bucovetsky, 1991; Wilson, 1991). If measured differences in tax-base elasticities were indeed due to tax-induced mobility, we should therefore observe larger elasticities (in absolute value) for small jurisdictions than for large jurisdictions.

\subsection{Sensitivity of the tax base to the tax rate}

As our baseline econometric model we adopt the following static semilogarithmic specification:

$\ln B_{i t}=\alpha T_{i t}+\widetilde{\alpha} \widetilde{T}_{i t}+\beta^{\prime} \mathbf{X}_{i t}+\gamma_{i} * t+\delta_{t}+\varepsilon_{i t}$,

where $i$ denotes cantons, $t$ denotes tax periods, $B$ is a measure of the relevant tax base, $T$ is a measure of $i$ 's average bequest tax rate, $\widetilde{T}$ is a measure of $i$ 's neighbours' average bequest tax rate, $\mathbf{X}$ is a vector of controls, $\alpha$ and $\widetilde{\alpha}$ are our coefficients of main interest, $\beta$ is a vector of coefficients, $\gamma$ and $\delta$ are fixed effects, and $\varepsilon$ is a stochastic error term.

Tax competition models are premised on a negative value of $\alpha$. A zero value of this parameter would suggest that the tax base is insensitive to the applied tax rate, and a positive value would suggest - implausibly if the model is properly specified - that the tax base is attracted by higher tax rates. By the same logic, we expect positive values of $\widetilde{\alpha}$, reflecting the fiscal externality implied by tax-base mobility. The implied own-tax elasticity of the tax base is given by $\alpha T_{i t}$.

Specification (1) includes fixed effects for tax periods $(\delta)$ and a canton-specific linear trend $\left(\gamma_{i} * t\right)$. We thereby control for all unobservable time-invariant canton-specific features affecting the tax base, such as central location or attractive landscapes; for stable canton-specific differences in the growth rate of tax bases; and for all relevant unobservable canton-invariant period-specific features, such as business cycles or policy changes at the federal level. Our specification of the empirical model forces identification of $\alpha$ to be based on canton-period idiosyncratic changes in the tax rate.

It is of course impossible to measure $B_{i t}$ with complete accuracy. The incidence of bequest taxation is an unknown quantity for taxpayers, as it depends on the timing of death as well as on the value of bequeathed assets at the time of death. We follow the literature in focusing on elderly and wealthy individuals as the tax base most directly concerned and thus most likely to respond to changes in bequest taxation. We use five alternative measures of the tax base $B_{i t}$ :

(A) The number of retired taxpayers,

(B) Pretax personal income of retired taxpayers,

(C) Federal income tax revenue from retired taxpayers,

(D) Federal income tax revenue from top-10\% income retired taxpayers,

(E) The ratio between federal income tax revenue from top-10\% retirees and federal income tax revenue from bottom- $25 \%$ retirees. ${ }^{14}$

Measure A allows us to explore whether changes in bequest taxation affect changes in retiree populations without weighting by income. Measure B can be thought of as measure A weighted by their pretax income. Measures $C$ and $D$ represent even more targeted proxies for the relevant tax base. The federal tax code applies identically across cantons, and it is strongly progressive (as are bequest taxes). Thus, variations in federal income tax revenue should capture mainly behavioural responses of high-income retirees. Moreover, tax revenue reflects the outcome of the full range of tax planning strategies and not only of residential choices. Measure D "zooms in" on tax revenue from retirees in the highest income decile. Given that bequest taxes are de facto even more progressive than the federal income tax, this represents our preferred proxy for the relevant tax base. For measure E, federal income tax revenue from top-income-decile retirees is divided by federal income tax revenue from bottom-income-quarter retirees. Thereby, measure E captures compositional changes among resident retiree populations.

\subsection{Estimation issues}

Estimation of Eq. (1) faces a number of econometric challenges. The three central issues concern reverse causality, timing, and inference.

The potential for reverse causality is simple to grasp. We seek to identify the effect of changes in tax rates on the size of the relevant tax base and on tax revenue, but causation could run either way. For instance, an

\footnotetext{
14 Precise variable definitions are given in Section 3.4.
} 


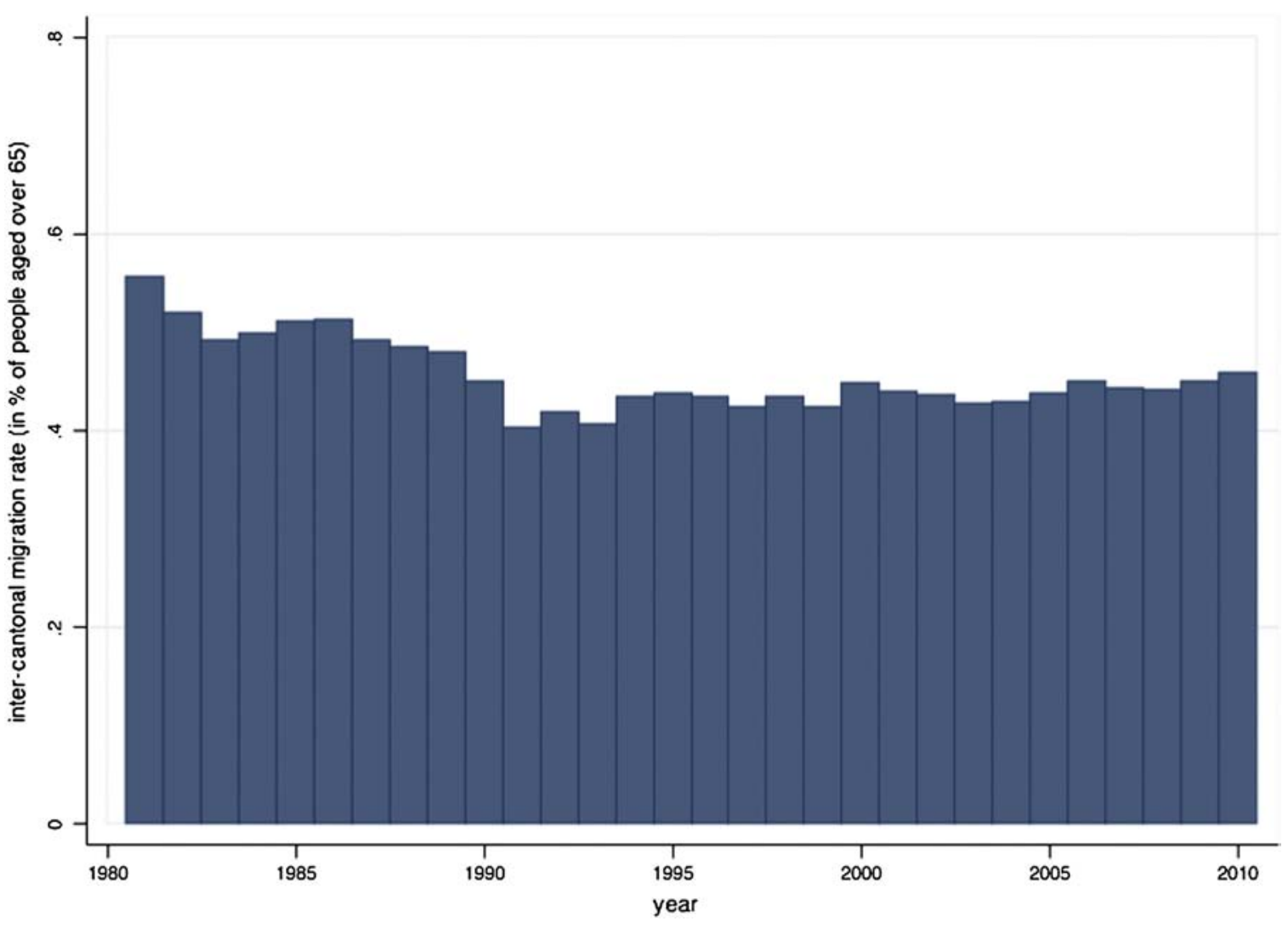

Note: Percentage of people aged over 65 migrating to another canton (sum of inter-cantonal in- and out-migrants aged over 65, divided by two, over the total number of people aged over 65). Data source: Swiss Federal Statistical Office.

Fig. 3. Historical pattern of elderly migration.

inflow of high-income elderly residents could strengthen political opposition to bequest taxation; or a period of buoyant bequest tax revenues might lead local governments to conclude that they can reduce tax rates without having to reduce expenditure below the desired level. These mechanisms would bias our estimate of the own-tax effect $\alpha$ away from zero. Conversely, an outflow of wealthy elderly residents could prompt cantons to lower their bequest taxes "defensively", which would bias our estimate towards zero. To solve this problem, we ideally would find an external instrument for changes in cantonal bequest tax schedules, but no convincingly exogenous variable that is related to changes in local bequest tax schedules is available. ${ }^{15}$ Yet, we argue that reverse causality is in fact unlikely to pose a serious problem here, for three reasons. First, elderly migrants on average over our sample period represented $0.46 \%$ of people over 65 or $0.07 \%$ of the total population (see Fig. 3). It would seem far fetched to assume that 1 year's inflow of residents of such magnitude would systematically affect bequest tax setting in that or the subsequent year. The politically relevant migration flows are even smaller than those we can measure, as they would comprise only Swiss nationals. Second, to the extent that they are linear, exogenous trends in elderly migration will be controlled for by our inclusion of canton-specific time trends. Third, in our estimations of dynamic version of Eq. (1), using system GMM, we implicitly employ transformed versions of the potentially endogenous tax variables as "internal" instruments.

\footnotetext{
15 One strategy we tried was to take advantage of the "domino-like" bequest tax reforms in Switzerland and to use as instruments (past) average bequest tax rates in neighbouring cantons. Results behave as expected with coefficient estimates closer to zero, but the instruments turn out to be weak. Results are available on request.
}

There are many conceivable ways of modelling the timing of tax effects. Our baseline contemporaneous model will not capture the full effects if migration patterns react sluggishly to changes in tax rates. That is why we also estimate a first-order autoregressive distributed lag $(\operatorname{ADL}(1,1))$ version of our baseline estimating equation:

$$
\begin{aligned}
\ln B_{i t}= & \lambda_{A D L, t-1} \ln B_{i t-1}+\alpha_{A D L, t} T_{i t}+\alpha_{A D L, t-1} T_{i t-1}+\beta_{A D L}^{\prime} \mathbf{X}_{A D L, i t} \\
& +\gamma_{A D L, i} * t+\delta_{A D L, t}+\varepsilon_{i t},
\end{aligned}
$$

where $\mathbf{X}_{A D L, i t}$ contains the controls of specification (1) plus the neighbour-canton bequest tax rates $\widetilde{T}_{i t}$ and $\widetilde{T}_{i t-1}$.

The ADL $(1,1)$ model nests the most widely used dynamic processes. For example, it can represent a "common factor" model with contemporaneous measured effects and autocorrelated errors. This would imply that $\alpha_{A D L, t-1}=-\alpha_{A D L, t} \lambda_{A D L, t-1}$. According to this model, the impact of changes in tax burdens on the tax base $B_{i t}$ fully materialises within year $t$, but there are persistent shocks to the stochastic component of the dependent variable. In addition, Eq. (2) also nests the $\operatorname{ADL}(1,0)$ model, implying that $\alpha_{A D L, t-1}=0$. The $\operatorname{ADL}(1,0)$ specification in turn can be derived from a number of theoretical bases, the most relevant of which is the "partial adjustment" model. In that model, the dependent variable responds sluggishly to changes in the explanatory variables, with geometrically declining lag weights. ${ }^{16}$ In our context, this represents delayed responses by tax bases and/or revenues to changes in tax rates, for example because migration decisions take time or because information disseminates slowly. In a dynamic setting

\footnotetext{
${ }^{16}$ For an exposition of common factor and partial adjustment models, see e.g. Davidson and McKinnon (2004, ch. 7 and 13).
} 
Table 3

Summary statistics.

\begin{tabular}{|c|c|c|c|c|c|}
\hline Dependent variables $^{\mathrm{a}}$ & Mean & Std. dev. & Min. & Max. & $\mathrm{N}$ \\
\hline (A) Number of retired taxpayers & $24,210.26$ & $29,227.42$ & 157 & 147,528 & 431 \\
\hline (B) Gross pretax income of retired taxpayers (in CHF 1000) & $1,155,399.99$ & $1,681,792.01$ & 5291 & $10,191,289$ & 431 \\
\hline (C) Federal income tax revenue from retired taxpayers (in CHF 1000) & $28,916.70$ & $45,614.68$ & 184 & 301,906 & 431 \\
\hline (D) Federal income tax revenue from top-10\% retired taxpayers (in CHF 1000) & $21,638.07$ & $35,299.39$ & 126 & 242,312 & 431 \\
\hline $\begin{array}{l}\text { (E) Federal income tax revenue from top-10\% retired taxpayers - federal income } \\
\text { tax revenue from bottom-25\% retired taxpayers (in CHF 1000) }\end{array}$ & $21,092.97$ & $34,832.07$ & 117 & 239,664 & 431 \\
\hline Explanatory variables & Mean & Std. dev. & Min. & Max. & $\mathrm{N}$ \\
\hline Average Inheritance Tax Rate (AITR) & 3.66 & 1.83 & 0 & 8.19 & 462 \\
\hline Average income tax rate on married taxpayer $(\%)^{c}$ & 11.28 & 1.75 & 5.42 & 15.13 & 462 \\
\hline Average wealth tax rate on married taxpayer $(\%)^{c}$ & 4.67 & 1.34 & 1.17 & 9.67 & 462 \\
\hline Population (in 100,000 ) & 2.61 & 2.74 & 0.13 & 13.35 & 462 \\
\hline \multicolumn{6}{|l|}{ Per capita public expenditure (in CHF 1000) on ... ${ }^{d}$} \\
\hline ... culture & 0.32 & 0.22 & 0.03 & 1.28 & 462 \\
\hline ... police & 0.34 & 0.17 & 0.07 & 1.01 & 462 \\
\hline ... health care & 1.44 & 0.94 & 0.04 & 5.66 & 462 \\
\hline$\ldots$ total & 9.17 & 4.05 & 2.83 & 28.80 & 462 \\
\hline House price index $(1970=100)^{\mathrm{e}}$ & 274.12 & 84.37 & 120.20 & 488.85 & 462 \\
\hline Share of foreign population (\%) & 15.73 & 6.72 & 4.94 & 37.68 & 462 \\
\hline Unemployment rate & 1.70 & 1.70 & 0 & 7.41 & 462 \\
\hline Prevalence of tax competition arguments ${ }^{\mathrm{f}}$ & 0.64 & 0.30 & 0 & 1 & 270 \\
\hline Tax increase ${ }^{g}$ & 0.19 & 0.39 & 0 & 1 & 462 \\
\hline
\end{tabular}

a Source: Swiss Federal Tax Administration. Statistics for the tax periods 1973/1974, 1975/1976, 1977/1978, 1979/1980, 1981/1982, 1983/1984, 1985/1986, 1989/1990, 1991/1992,

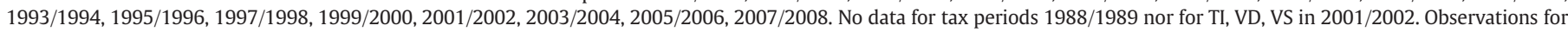

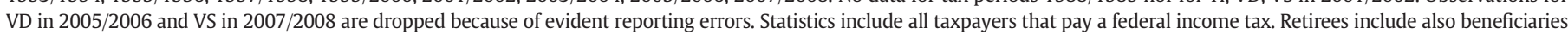
of invalidity benefits and people that work while receiving a pension.

b See Appendix A for details.

c Population-weighted cantonal averages of consolidated cantonal and municipal tax rates. Income tax rate is the average of tax rates on gross annual income of $\mathrm{CHF} 20,000,50,000$,

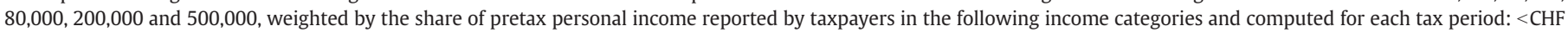

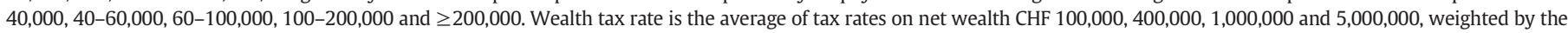

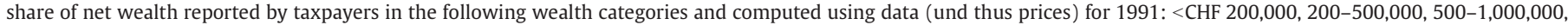
$\geq 1,000,000$. Data source: Swiss Federal Tax Administration.

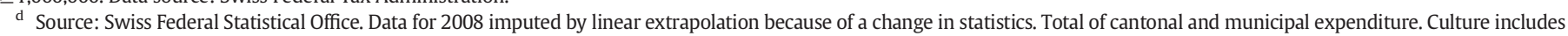
culture, sport and religion; police includes fire service and police.

e House price index by region: Zurich (ZH, SH), East (AI, AR, SG, TG), Centre (GL, LU, NW, OW, SZ, UR, ZG), North-West (AG, BL, BS, SO), Berne (BE), South (GR, TI, VS), Lake Geneva (GE, VD), other French-speaking (FR, JU, NE). This index was provided to us by Wüest \& Partner (a consultancy firm).

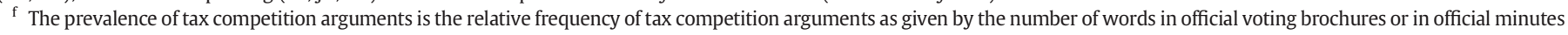
of parliamentary debates (see Section 2.2).

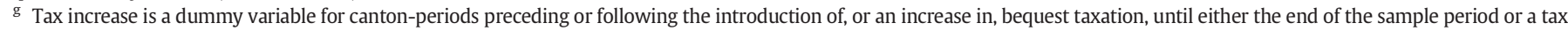

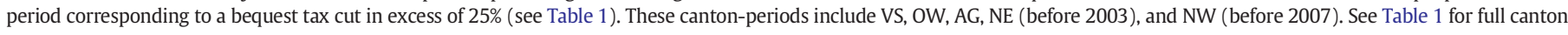
names.

within a short panel, the fixed-effects OLS estimator is not consistent (Nickell, 1981). This, in addition to allowing us to instrument the tax variables, is why we estimate our dynamic specifications using the system GMM estimator.

Finally, inference needs to take account of the panel structure of our data. Errors could be correlated over time within cantons despite the inclusion of canton-specific fixed effects and time trends. Regression errors may in addition be (spatially) correlated across cantons within given years. With the estimates of Eq. (1), we therefore report standard errors that are two-way clustered, by canton and by tax period, following Cameron et al. (2011). For specification (2), we report standard errors clustered by canton.

\subsection{Data}

Our measures of the tax base are constructed using individual-level data from federal income tax statistics. These data are currently available for the period 1973 to 2008 . They cover the universe of taxpayers liable to pay federal income tax, thus excluding taxpayers with an annual personal income below a certain threshold. ${ }^{17}$ Measure (A) consists of the number of taxpayers coded as retirees. Measures (B) and (C) are pretax personal income and federal income tax revenue from these retirees, respectively. Measure (D) is the federal income tax revenue

\footnotetext{
17 This threshold was CHF 16,000 (CHF 27,000 for couples) in 2008. Over our sample period the average exchange rate was 1.60 Swiss francs (CHF) to the US dollar.
}

from top-10\% income retirees and measure $(\mathrm{E})$ is the ratio between the federal income tax revenue from top-10\% and bottom-25\% income retirees. Bottom-25\% and top-10\% incomes are calculated for the nationwide population of retired taxpayers in each tax period. They correspond to pretax incomes of CHF 32,000 and CHF 99,800 in 2008, respectively. Tax collection changed during our sample period from a biannual to an annual system, and the timing of this change differed across cantons. We therefore aggregate all data into 2-year averages. Our dataset thus spans up to 26 cantons and 17 "tax periods". ${ }^{18}$ Summary statistics are given in Table 3 .

Our main measure of the relevant tax rate, $T_{i t}$, is designed to quantify a representative bequest tax burden. We construct the Average Inheritance Tax Rate (AITR) as a weighted average - across different bequest size classes and categories of heirs - of effective inheritance tax rates. Weights are defined by the frequency of observed bequests in each class, using data for the canton of Vaud (as national data do not exist). A detailed description is provided in the Appendix A. ${ }^{19}$

\footnotetext{
18 The canton of Jura was created in 1979 by separating from the canton of Berne. Data for these two cantons are excluded prior to 1979. For unknown reasons, all data for the 1988-1989 period, as well as some canton-level data for other periods, are missing from the federal income tax database (see notes to Table 3).

19 As an alternative to this measure, we have estimated all our models using the highest statutory tax rate that is recorded in federal statistics, i.e. the average effective tax rate on an inheritance of CHF 500,000 by a direct descendant. Our estimates of tax-base elasticities turned out not to be qualitatively affected by this choice. Results are available on request
} 
Table 4

Responsiveness of the tax base: baseline regressions.

\begin{tabular}{|c|c|c|c|c|c|}
\hline & (A) & (B) & (C) & (D) & $(\mathrm{E})$ \\
\hline & $\begin{array}{l}\text { Number of } \\
\text { retirees }\end{array}$ & $\begin{array}{l}\text { Gross personal income } \\
\text { by retirees }\end{array}$ & $\begin{array}{l}\text { FIT revenue from } \\
\text { retirees }\end{array}$ & $\begin{array}{l}\text { FIT revenue from } \\
\text { retirees: top-10\% }\end{array}$ & $\begin{array}{l}\text { FIT revenue from retirees: } \\
\text { top-10\%-bottom- } 25 \%\end{array}$ \\
\hline \multicolumn{6}{|l|}{ No controls included } \\
\hline AITR (\%) & $\begin{array}{r}-0.002 \\
(0.031)\end{array}$ & $\begin{array}{r}-0.027 \\
(0.033)\end{array}$ & $\begin{array}{r}-0.048 \\
(0.052)\end{array}$ & $\begin{array}{r}-0.061 \\
(0.057)\end{array}$ & $\begin{array}{r}-0.122^{*} \\
(0.065)\end{array}$ \\
\hline Elasticity at mean AITR & -0.007 & -0.099 & -0.174 & -0.223 & -0.441 \\
\hline Lower bound of confidence interval on elasticity at mean AITR & -0.229 & -0.336 & -0.543 & -0.631 & -0.903 \\
\hline Upper bound of confidence interval on elasticity at mean AITR & 0.215 & 0.137 & 0.194 & 0.186 & 0.020 \\
\hline Implied AITR at which elasticity $=-1$ & 500.4 & 36.6 & 20.8 & 16.3 & 8.2 \\
\hline Implied minimum AITR at which elasticity is not sign. diff. from -1 & 15.9 & 10.8 & 6.7 & 5.8 & 4.0 \\
\hline \multicolumn{6}{|l|}{ Full set of controls included } \\
\hline AITR (\%) & $\begin{array}{c}0.015 \\
(0.027)\end{array}$ & $\begin{array}{r}-0.007 \\
(0.026)\end{array}$ & $\begin{array}{r}-0.016 \\
(0.043)\end{array}$ & $\begin{array}{r}-0.026 \\
(0.047)\end{array}$ & $\begin{array}{r}-0.118 \\
(0.072)\end{array}$ \\
\hline Income tax rate $(\%)$ & $\begin{array}{c}-0.029^{* *} \\
(0.013)\end{array}$ & $\begin{array}{l}-0.046^{* * *} \\
(0.015)\end{array}$ & $\begin{array}{c}-0.060^{* *} \\
(0.028)\end{array}$ & $\begin{array}{c}-0.072^{* *} \\
(0.034)\end{array}$ & $\begin{array}{r}-0.102^{*} \\
(0.059)\end{array}$ \\
\hline Wealth tax rate $(\%)$ & $\begin{array}{c}-0.001 \\
(0.026)\end{array}$ & $\begin{array}{r}-0.000 \\
(0.023)\end{array}$ & $\begin{array}{c}-0.024 \\
(0.032)\end{array}$ & $\begin{array}{r}-0.028 \\
(0.033)\end{array}$ & $\begin{array}{r}-0.036 \\
(0.098)\end{array}$ \\
\hline Elasticity at mean AITR & 0.055 & -0.026 & -0.057 & -0.094 & -0.429 \\
\hline Lower bound of confidence interval on elasticity at mean AITR & -0.135 & -0.211 & -0.359 & -0.431 & -0.943 \\
\hline Upper bound of confidence interval on elasticity at mean AITR & 0.245 & 0.160 & 0.245 & 0.242 & 0.086 \\
\hline Implied AITR at which elasticity $=-1(\%)$ & -66.3 & 140.4 & 63.7 & 38.5 & 8.5 \\
\hline Implied minimum AITR at which elasticity is not sign. diff. from $-1(\%)$ & 26.9 & 17.2 & 10.1 & 8.4 & 3.8 \\
\hline Elasticity at mean income tax rate & -0.333 & -0.522 & -0.674 & -0.809 & -1.153 \\
\hline Lower bound of confidence interval on elasticity at mean income tax rate & -0.630 & -0.856 & -1.302 & -1.558 & -2.449 \\
\hline Upper bound of confidence interval on elasticity at mean income tax rate & -0.036 & -0.188 & -0.046 & -0.059 & 0.142 \\
\hline Implied income tax rate at which elasticity $=-1(\%)$ & 33.9 & 21.6 & 16.8 & 14.0 & 9.8 \\
\hline $\begin{array}{l}\text { Implied minimum income tax rate at which elasticity is not sign. } \\
\text { diff. from }-1(\%)\end{array}$ & 17.9 & 13.2 & 8.7 & 7.3 & 4.6 \\
\hline Elasticity at mean wealth tax rate & -0.005 & 0.000 & -0.114 & -0.130 & -0.167 \\
\hline Lower bound of confidence interval on elasticity at mean wealth tax rate & -0.244 & -0.207 & -0.407 & -0.433 & -1.060 \\
\hline Upper bound of confidence interval on elasticity at mean wealth tax rate & 0.234 & 0.206 & 0.180 & 0.174 & 0.725 \\
\hline Implied wealth tax rate at which elasticity $=-1(\%)$ & 944.1 & 9725.1 & 41.0 & 36.0 & 27.9 \\
\hline $\begin{array}{l}\text { Implied minimum wealth tax rate at which elasticity is not sign. } \\
\text { diff. from }-1(\%)\end{array}$ & 19.1 & 22.6 & 11.5 & 10.8 & 4.4 \\
\hline
\end{tabular}

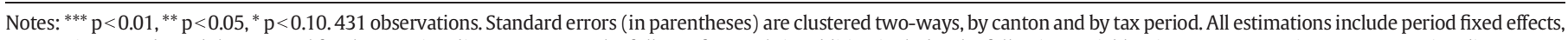

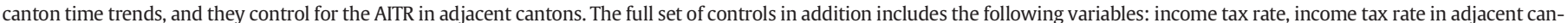

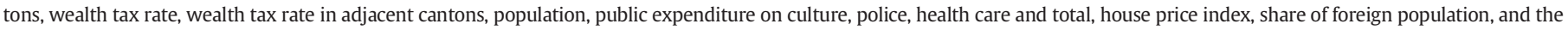

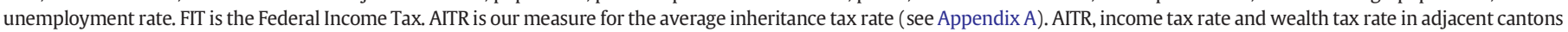

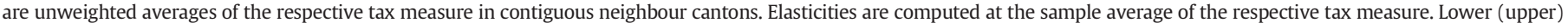
bounds and implied tax rates at which elasticities are not statistically significantly different from -1 are computed for a $95 \%$ confidence interval.

The sample average AITR is $3.7 \%$, with a maximum of $8.2 \%$ and a standard deviation of 1.8 percentage points (Table 3 ). These values could appear small, but they probably represent an empirical setting with greater identifying variation of tax burdens than that provided by the United States. The most directly comparable measure for the United States is Bakija and Slemrod's (2004, Table 4) "effective state average estate and inheritance tax rate", with a mean value of $0.7 \%$, a maximum of $7.7 \%$ and a sample standard deviation of 1.4 percentage points. $^{20}$

In addition to including canton and tax period fixed effects and canton-level time trends, we seek to control for all other potentially relevant tax variables that vary by canton and tax period and that could plausibly affect migration decisions. We thus include the AITR of adjacent cantons computed as unweighted averages of the tax burdens of contiguous neighbour cantons, income and wealth tax rates for high-income taxpayers, and average income and wealth tax rates of adjacent cantons. Furthermore, we include a range of

\footnotetext{
${ }^{20}$ These measures are computed net of the federal estate tax rate, which offers no interstate variation.
}

time-varying non-tax controls that could conceivably affect location choices of high-income elderly residents: total population; public expenditure on culture, police, health care, and total public expenditure; real estate prices; the share of foreign residents and the cantonlevel unemployment rate.

\section{Results}

\subsection{Baseline estimates}

Table 4 shows estimates of the responsiveness to bequest tax rates (AITR) of our five alternative measures of the tax base, using specification (1). In the upper panel of the table, we report models that exclude all controls, thus assuming that $\beta^{\prime}=0$, whereas the full set of controls is included to generate the results given in the lower panel of Table 4.

In line with expectations, the effects of bequest tax rates are estimated to be negative in most specifications, and they increase in absolute value as we "zoom in" on high-income retirees by moving from measure A to measure E. However, these estimates are (borderline) statistically significant only when we take the log of the ratio between federal income 
Table 5

Responsiveness of the tax base: robustness checks.

\begin{tabular}{|c|c|c|c|c|c|}
\hline & (A) & (B) & (C) & (D) & $(\mathrm{E})$ \\
\hline & Number of retirees & $\begin{array}{l}\text { Gross personal income } \\
\text { by retirees }\end{array}$ & FIT revenue from retirees & $\begin{array}{l}\text { FIT revenue from retirees: } \\
\text { top- } 10 \%\end{array}$ & $\begin{array}{l}\text { FIT revenue from retirees: } \\
\text { top-10\%-bottom- } 25 \%\end{array}$ \\
\hline \multicolumn{6}{|l|}{ Panel A: autoregressive model (375 obs.) } \\
\hline \multicolumn{6}{|l|}{ No controls included } \\
\hline AITR $(\%)$ & $\begin{array}{c}-0.023 \\
(0.017)\end{array}$ & $\begin{array}{r}-0.046^{*} \\
(0.024)\end{array}$ & $\begin{array}{c}-0.105^{* *} \\
(0.044)\end{array}$ & $\begin{array}{c}-0.134^{* *} \\
(0.060)\end{array}$ & $\begin{array}{c}-0.124 \\
(0.075)\end{array}$ \\
\hline \multirow[t]{2}{*}{$\operatorname{AITR}(t-1)$} & 0.027 & 0.028 & 0.056 & 0.071 & 0.042 \\
\hline & $(0.017)$ & $(0.019)$ & $(0.041)$ & $(0.048)$ & $(0.073)$ \\
\hline \multirow[t]{2}{*}{ Dependent variable $(t-1)$} & $0.605^{* * *}$ & $0.567^{* * *}$ & $0.551^{* * *}$ & $0.493^{* * *}$ & $0.512^{* * *}$ \\
\hline & $(0.043)$ & $(0.057)$ & $(0.067)$ & $(0.089)$ & $(0.069)$ \\
\hline Long-term elasticity at mean AITR & 0.034 & -0.150 & -0.387 & -0.443 & -0.609 \\
\hline Lower bound of confidence interval on long-term elasticity at mean AITR & -0.273 & -0.499 & -0.959 & -1.123 & -1.424 \\
\hline Upper bound of confidence interval on long-term elasticity at mean AITR & 0.341 & 0.198 & 0.184 & 0.238 & 0.205 \\
\hline Implied AITR at which long-term elasticity $=-1(\%)$ & -105.4 & 24.0 & 9.3 & 8.1 & 5.9 \\
\hline Implied minimum AITR at which long-term elasticity is not sign. diff. from $-1(\%)$ & 13.2 & 7.3 & 3.8 & 3.3 & 2.6 \\
\hline \multicolumn{6}{|l|}{ Full set of controls included } \\
\hline \multirow[t]{2}{*}{$\operatorname{AITR}(\%)$} & 0.001 & -0.013 & -0.036 & -0.038 & -0.064 \\
\hline & $(0.014)$ & $(0.015)$ & $(0.029)$ & $(0.039)$ & $(0.062)$ \\
\hline \multirow[t]{2}{*}{$\operatorname{AITR}(t-1)$} & 0.015 & 0.010 & 0.021 & 0.031 & 0.029 \\
\hline & $(0.013)$ & $(0.014)$ & $(0.032)$ & $(0.039)$ & $(0.062)$ \\
\hline Dependent variable $(t-1)$ & $\begin{array}{l}0.489^{* * * *} \\
(0.051)\end{array}$ & $\begin{array}{l}0.441^{* * * *} \\
(0.067)\end{array}$ & $\begin{array}{l}0.468^{* * * *} \\
(0.050)\end{array}$ & $\begin{array}{l}0.427^{* * *} \\
(0.068)\end{array}$ & $\begin{array}{l}0.462^{* * * *} \\
(0.069)\end{array}$ \\
\hline Long-term elasticity at mean AITR & 0.108 & -0.018 & -0.100 & -0.048 & -0.236 \\
\hline Lower bound of confidence interval on long-term elasticity at mean AITR & -0.096 & -0.229 & -0.451 & -0.423 & -0.766 \\
\hline Upper bound of confidence interval on long-term elasticity at mean AITR & 0.312 & 0.194 & 0.252 & 0.327 & 0.294 \\
\hline Implied AITR at which long-term elasticity $=-1(\%)$ & -33.4 & 205.2 & 36.2 & 74.6 & 15.3 \\
\hline Implied minimum AITR at which long-term elasticity is not sign. diff. from -1 (\%) & 37.4 & 15.8 & 8.0 & 8.6 & 4.8 \\
\hline \multicolumn{6}{|l|}{ Panel B: differential effects by population size (431 obs.) } \\
\hline \multicolumn{6}{|l|}{ No controls included } \\
\hline \multirow[t]{2}{*}{ AITR $(\%)$} & -0.004 & -0.031 & -0.050 & -0.063 & $-0.107^{* *}$ \\
\hline & $(0.031)$ & $(0.032)$ & $(0.049)$ & $(0.053)$ & $(0.053)$ \\
\hline \multirow{2}{*}{ Population * AITR } & -0.003 & -0.005 & -0.003 & -0.002 & 0.025 \\
\hline & $(0.008)$ & $(0.008)$ & $(0.010)$ & $(0.011)$ & $(0.023)$ \\
\hline Elasticity at mean AITR in a canton of average size & -0.015 & -0.113 & -0.181 & -0.227 & -0.389 \\
\hline Lower bound of confidence interval on elasticity at mean AITR in a canton of av. size & -0.238 & -0.339 & -0.529 & -0.608 & -0.768 \\
\hline Upper bound of confidence interval on elasticity at mean AITR in a canton of av. size & 0.208 & 0.114 & 0.166 & 0.153 & -0.010 \\
\hline \multicolumn{6}{|l|}{ Full set of controls included } \\
\hline \multirow[t]{2}{*}{ AITR $(\%)$} & 0.018 & -0.005 & -0.006 & -0.013 & -0.093 \\
\hline & $(0.028)$ & $(0.026)$ & $(0.040)$ & $(0.043)$ & $(0.062)$ \\
\hline Population * AITR & $\begin{array}{c}0.003 \\
(0.006)\end{array}$ & $\begin{array}{c}0.003 \\
(0.006)\end{array}$ & $\begin{array}{c}0.012 \\
(0.009)\end{array}$ & $\begin{array}{c}0.016 \\
(0.010)\end{array}$ & $\begin{array}{c}0.036 \\
(0.023)\end{array}$ \\
\hline Elasticity at mean AITR in a canton of average size & 0.065 & -0.018 & -0.021 & -0.047 & -0.337 \\
\hline Lower bound of confidence interval on elasticity at mean AITR in a canton of av. size & -0.136 & -0.205 & -0.304 & -0.356 & -0.776 \\
\hline Upper bound of confidence interval on elasticity at mean AITR in a canton of av. size & 0.266 & 0.169 & 0.263 & 0.261 & 0.102 \\
\hline
\end{tabular}


Panel C: differential effects by prevalence of pro-reform arguments (249 obs.) No controls included

AITR (\%)

Prevalence of tax comp. arguments * AITR

\begin{tabular}{|c|c|c|c|c|}
\hline $\begin{array}{c}-0.018 \\
(0.027) \\
-0.016 \\
(0.088)\end{array}$ & $\begin{array}{c}-0.030 \\
(0.037) \\
-0.072 \\
(0.115)\end{array}$ & $\begin{array}{c}-0.049 \\
(0.056) \\
-0.183 \\
(0.165)\end{array}$ & $\begin{array}{c}-0.050 \\
(0.063) \\
-0.203 \\
(0.181)\end{array}$ & $\begin{array}{c}-0.080 \\
(0.062) \\
-0.078 \\
(0.159)\end{array}$ \\
\hline $\begin{array}{r}-0.079 \\
-0.308 \\
0.151\end{array}$ & $\begin{array}{r}-0.133 \\
-0.453 \\
0.188\end{array}$ & $\begin{array}{r}-0.214 \\
-0.693 \\
0.266\end{array}$ & $\begin{array}{r}-0.222 \\
-0.768 \\
0.325\end{array}$ & $\begin{array}{r}-0.353 \\
-0.884 \\
0.177\end{array}$ \\
\hline $\begin{array}{c}-0.003 \\
(0.019) \\
-0.052 \\
(0.060)\end{array}$ & $\begin{array}{c}-0.001 \\
(0.022) \\
-0.140^{* *} \\
(0.061)\end{array}$ & $\begin{array}{c}0.005 \\
(0.034) \\
-0.320^{* * *} \\
(0.080)\end{array}$ & $\begin{array}{c}0.017 \\
(0.040) \\
-0.386^{* * *} \\
(0.086)\end{array}$ & $\begin{array}{c}0.016 \\
(0.040) \\
-0.355^{* * *} \\
(0.120)\end{array}$ \\
\hline $\begin{array}{r}-0.012 \\
-0.172 \\
0.148\end{array}$ & $\begin{array}{r}-0.005 \\
-0.195 \\
0.185\end{array}$ & $\begin{array}{r}0.021 \\
-0.269 \\
0.311\end{array}$ & $\begin{array}{r}0.075 \\
-0.266 \\
0.416\end{array}$ & $\begin{array}{r}0.070 \\
-0.279 \\
0.418\end{array}$ \\
\hline $\begin{array}{c}-0.002 \\
(0.027) \\
0.018 \\
(0.040)\end{array}$ & $\begin{array}{c}-0.014 \\
(0.033) \\
-0.014 \\
(0.045)\end{array}$ & $\begin{array}{c}-0.018 \\
(0.048) \\
-0.051 \\
(0.068)\end{array}$ & $\begin{array}{c}-0.016 \\
(0.055) \\
-0.091 \\
(0.075)\end{array}$ & $\begin{array}{r}-0.050 \\
(0.055) \\
-0.221^{*} \\
(0.113)\end{array}$ \\
\hline $\begin{array}{r}0.057 \\
-0.260 \\
0.373\end{array}$ & $\begin{array}{r}-0.100 \\
-0.438 \\
0.238\end{array}$ & $\begin{array}{r}-0.248 \\
-0.810 \\
0.313\end{array}$ & $\begin{array}{r}-0.390 \\
-1.006 \\
0.227\end{array}$ & $\begin{array}{l}-0.983 \\
-1.775 \\
-0.191\end{array}$ \\
\hline $\begin{array}{c}0.016 \\
(0.017) \\
0.022 \\
(0.033)\end{array}$ & $\begin{array}{c}0.011 \\
(0.017) \\
-0.017 \\
(0.036)\end{array}$ & $\begin{array}{c}0.032 \\
(0.035) \\
-0.089 \\
(0.060)\end{array}$ & $\begin{array}{c}0.039 \\
(0.039) \\
-0.136^{* *} \\
(0.068)\end{array}$ & $\begin{array}{c}-0.016 \\
(0.060) \\
-0.300^{* * *} \\
(0.110)\end{array}$ \\
\hline $\begin{array}{r}0.140 \\
-0.138 \\
0.418\end{array}$ & $\begin{array}{r}-0.024 \\
-0.318 \\
0.270\end{array}$ & $\begin{array}{r}-0.207 \\
-0.672 \\
0.259\end{array}$ & $\begin{array}{r}-0.351 \\
-0.852 \\
0.149\end{array}$ & $\begin{array}{l}-1.144 \\
-1.807 \\
-0.482\end{array}$ \\
\hline
\end{tabular}

Elasticity at mean AITR in a canton with average prevalence of tax comp. arg.

Lower bound of conf. int. on elasticity at mean AITR in a cant. with av. prevalence

Upper bound of conf. int. on elasticity at mean AITR in a cant. with av, prevalence

Full set of controls included

AITR (\%)

Prevalence of tax comp. arguments * AITR

Elasticity at mean AITR in a canton with average prevalence of tax comp. arg.

Lower bound of conf. int. on elasticity at mean AITR in a cant. with av. prevalence

Upper bound of conf. int. on elasticity at mean AITR in a cant. with av. prevalence

Panel D: differential effects by sign of tax changes (431 obs.)

No controls included

AITR (\%)

Tax increase dummy * AITR

Elasticity at mean AITR in canton-periods with tax increase

Lower bound of conf. int. on elasticity at mean AITR in canton-periods with tax increase

Upper bound of conf. int. on elasticity at mean AITR in canton-periods with tax increase

0.270

0.259

$-0.482$

Lower bound of conf int on elasticity at mean ATTR in canton-periods with tax increase Upper bound of conf. int. on elasticity at mean AITR in canton-periods with tax increase

$(0.040)$

0.070

0.418

0.050

$-0.221^{*}$

$(0.113)$

$-0.983$

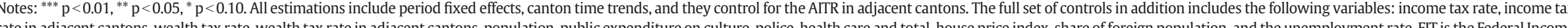

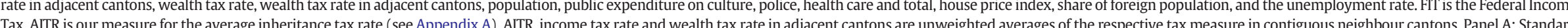

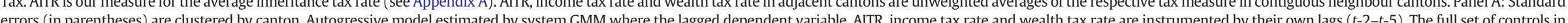

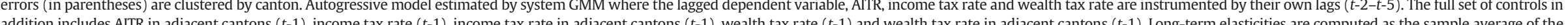

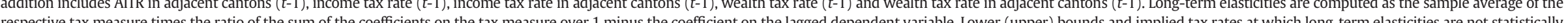

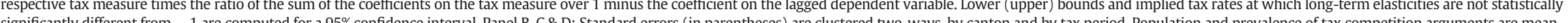

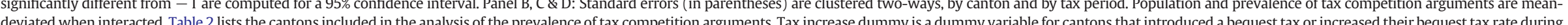

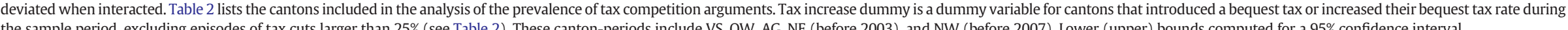
the sample period, excluding episodes of tax cuts larger than 25\% (see Table 2). These canton-periods include VS, OW, AG, NE (before 2003), and NW (before 2007). Lower (upper) bounds computed for a 95\% confidence interval. 
tax revenue from top-10\% and bottom-25\% retirees as the dependent variable (measure E) and omit the controls. This suggests that, overall, changes in bequest tax burdens have no statistically significant effect on the corresponding tax base except, just about, for the highest-income class of retirees. However, the apparent compositional effect captured by measure $\mathrm{E}$ is not strong enough to allow us to reject the hypothesis that changes in bequest tax rates had no effect on the size of the overall tax base of the relevant cantons (measures B to D). ${ }^{21}$

Below the coefficient estimates in the two panels of Table 4, we show the implied elasticities evaluated at the sample average tax rates, together with their associated 95\% confidence bounds. If we focus on measures $B$ to $D$, which get closest to capturing the relevant tax base, the point estimates of these elasticities range from -0.026 to -0.223 . Based on the confidence intervals, we can never reject the hypothesis of a zero elasticity but always reject the hypothesis of a unit elasticity. The lower bounds of the confidence intervals range from -0.211 to -0.631 (measures B to D), which is considerably above the value of -1 that would be consistent with revenue-neutral tax cuts. ${ }^{22}$

These results are for elasticities evaluated at the sample mean AITR. Our log-linear regression specifications, however, imply increasing taxbase elasticities at higher tax rates. In the two bottom lines of each panel of Table 4, we therefore report two out-of-sample predicted values to gauge the level of tax rates at which bequest taxation could become self-defeating in revenue terms. ${ }^{23}$ First, we show the AITR corresponding to the point estimate that would imply an elasticity of -1 . If we concentrate again on the tax-base proxies (measures B to D), we find that the lowest such rate equals $16.3 \%$ (measure D, no controls) - twice the sample maximum of $8.2 \%$ (see Table 3 ). According to our preferred estimate (measure $\mathrm{D}$, with controls), the tax-base elasticity would exceed unity for a bequest tax rate above $38.5 \%$.

Since point estimates are subject to sampling error, we also report a less demanding estimate: the minimum AITR at which we cannot reject the hypothesis of a unit elasticity at the $95 \%$ confidence level. This alternative out-of-sample estimate can be interpreted as the AITR above which our estimates imply that, conditional on covariates, revenuerising tax cuts could be possible. With this measure, our lowest estimate of a potentially revenue-neutral AITR is $5.8 \%$ (measure D, no controls), with the corresponding estimate in the preferred model ( $\mathrm{D}$, with controls) being $8.4 \%$. Even if we take the lowest of these estimates (5.8\%), we note that only $12 \%$ of our sample AITRs exceed that threshold. Moreover, as can be gleaned from Fig. 1, these relatively high tax rates were only applied in the French-speaking cantons of Western Switzerland (Fribourg, Geneva, Neuchâtel and Vaud), all of which adopted major bequest tax reforms only after the turn of the century. The Germanspeaking cantons which initiated the wave of reforms all started from lower average bequest tax burdens.

These estimates suggest that bequest tax reforms most likely were associated with less than proportional changes in tax bases. They also imply that the threshold level above which increases in bequest taxation would be revenue reducing could be rather low. Our preferred estimate of this critical value is an AITR of 8.4\%. Our estimates thus imply that revenue-maximising bequest tax rates, when set independently by small jurisdictions such as Swiss cantons, may well be lower than some bequest tax rates observed internationally.

\footnotetext{
21 Estimated cross-canton effects ( $\widetilde{\alpha}$, not shown in Table 4 to save space) are statistically insignificant throughout. This further corroborates a lack of sensitivity of the tax base to changes in the tax rate.

${ }^{22}$ For an estimation of the overall revenue-maximising bequest tax rate, tax payments of migrants while still alive also need to be considered. It can be shown that the corresponding elasticity is close to -1 for Switzerland, at least in the short run.

${ }_{23}$ Since, for our preferred measures $C$ and $D$, our dependent variable is measured in terms of income tax payments (of the living), the corresponding elasticity estimates should be a good approximation of the effects of behavioural responses not just on bequest tax revenues but on tax revenue overall.
}

The corresponding personal income and wealth tax rates at which the implied tax-base elasticity is unity are $14 \%$ and $36 \%$, respectively (Table 4, bottom panel, measure D). Both these estimates substantially exceed sample average tax rates, though the critical income-tax threshold of $14 \%$ is below the sample maximum of $15.3 \%$ (Table 3 ). The coefficients on income tax rates in particular are both larger (in absolute value) and more precisely estimated than those on bequest tax rates, suggesting that high-income retirees attach greater weight to income taxation than to bequest taxation.

\subsection{Robustness}

In Table 5, we subject our baseline results to a range of sensitivity tests. First, we estimate the $\operatorname{ADL}(1,1)$ specification of Eq. (2). These results are shown in Panel A. Implied long-run elasticities are computed from the implied long-run coefficients $\left(\alpha_{A D L, t}+\alpha_{A D L, t-1}\right) /\left(1-\lambda_{A D L, t}-1\right)$. Elasticities are again reported together with their associated confidence intervals, and we compute out-of-sample estimates of the tax rates at which the implied elasticity would equal one, or for which we could not reject such a hypothesis at the $95 \%$ confidence level. The dynamic specifications produce somewhat smaller estimated bequest-tax-base responses than the static specifications of Table 4 . In no case can we reject the hypothesis that the long-run tax-base elasticity at the mean AITR equals zero, and in two specifications we also cannot reject the hypothesis that the long-run elasticity is equal to -1 . As a consequence of the wider confidence bands, the implied AITRs above which one cannot statistically reject the unit-elasticity hypothesis are somewhat lower than in the static specifications. Reassuringly, however, the main threshold estimate (measure $\mathrm{D}$, with controls) of $8.6 \%$ is similar to the corresponding estimate in the static model of $8.4 \%$. The associated point estimate is an AITR of $74.6 \%$ - almost double our preferred (because more tightly estimated) value of $38.5 \%$ from the static model. Interestingly, though, the corresponding long-run point estimate for measure $\mathrm{C}$ is $36.2 \%$, close to our central estimate from the baseline regressions.

In Panel B of Table 5, we allow the tax-base effect of bequest tax rates to vary by jurisdiction size. The motivation underlying this specification is that models of asymmetric tax competition lead us to expect the taxbase elasticity to be inversely correlated with jurisdiction size, implying a positive coefficient on the interaction term between the AITR and the size of cantons (in terms of their populations). The estimated coefficients on the interaction term, however, turn out to be small, often negative, and statistically insignificant throughout.

Other interjurisdictional differences affecting tax-base elasticities could, however, be at play. In Panel C of Table 5, we examine the hypothesis that policy makers were aware of such differences and that this awareness is observable through the weight given to the tax competition argument in official voting brochures. We therefore interact the AITR with a variable measuring the prevalence of tax competition arguments (see Table 2). Since this requires us to focus on reforms for which official brochures were issued, our sample size shrinks by nearly one-half. We find consistently negative coefficient estimates on the interaction terms, and in our preferred specifications (measures $C$ and $\mathrm{D}$, with controls), these estimates are statistically significant. It therefore appears that the intensity with which the tax competition argument was invoked did correlate positively with the relevant canton's tax-base elasticity. However, we can again never reject the hypothesis of a zero elasticity at the sample mean AITR and "prevalence". Even in the cases where this interaction term takes large values - i.e. where the pre-reform bequest tax burden was relatively high and the tax competition argument was invoked particularly prominently - our estimated elasticities are far below unity. As an illustrative example, take the canton of Schaffhausen, whose bequest tax reform in 1991 is generally considered as having triggered the subsequent wave of reforms (see Table 2 and Fig. 1). Evaluated at its pre-reform AITR and considering that its official pro-reform argument was entirely based on tax 


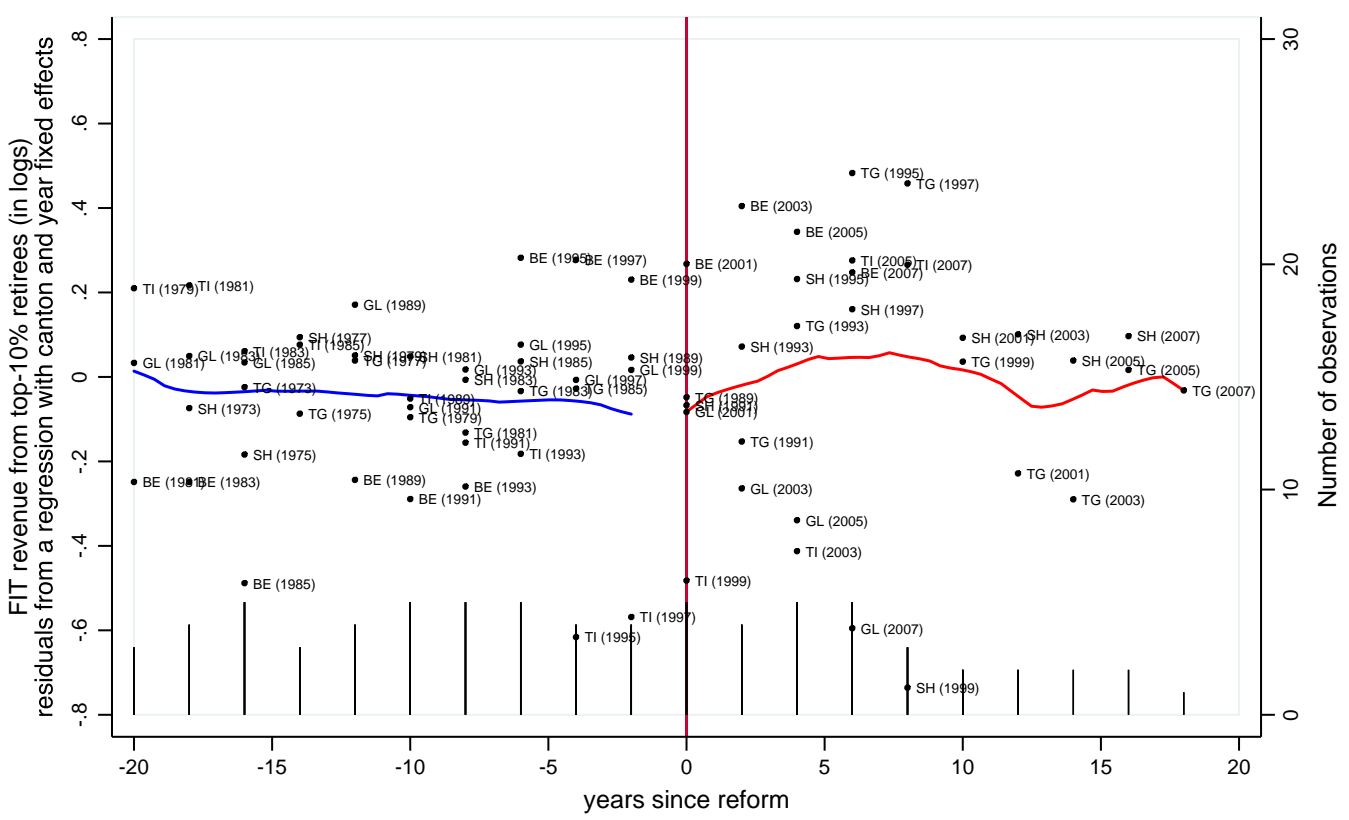

Average FIT revenue from top-10\% retirees before reform (smoothed line)

Average FIT revenue from top-10\% retirees after reform (smoothed line)

Note: Points are residuals from a regression of federal income tax revenue from the top $10 \%$ retirees (in logs) on canton and year fixed affects in the five cantons with the largest tax cuts ( $\geq 40 \%$ of the AITR) occuring at least four years after the start and four years before the end of our sample period. Lines are obtained through Epanechnikov kernel-weighted local polynomial smoothing of degree one. Spikes above the horizontal axis represent the number of observations.

Fig. 4. Long-term effect of bequest tax reforms on federal income tax revenue from top-10\% retirees.

competition (Table 2), the implied elasticity of federal income tax revenue from the top income decile of retirees (measure D) equals -0.59 . The $p$ value of a test that the true elasticity equals -1 is 0.15 . Hence, taken at face value, our estimates imply that even the first mover in the wave of Swiss bequest tax reforms was highly unlikely to have faced conditions in which its tax cut was revenue neutral.

As a final robustness test, we explore differential tax-base responses to increases and to decreases in bequest tax rates, by adding an interaction term between the AITR and a dummy for canton-periods associated with increasing AITRs (Table 5, Panel D). The interaction term is generally negative, and the main effects increase compared to the values found in the baseline estimates of Table 4. In our preferred specification (measure D, with controls), the interaction effect is statistically significantly negative, while the main effect even turns positive. These results imply that the tax base responded statistically significantly to tax increases but not to tax cuts. The tax-base elasticity associated with tax increases is -0.35 , which is still far from -1 but considerably larger in absolute value than -0.09 , the tax-base elasticity associated with all tax changes combined (Table 4, measure $\mathrm{D}$, with controls).

\subsection{Long-term effects}

Migration responses to changes in bequest tax burdens are unlikely to be instantaneous. The fact that we work with 2-year periods and that we have considered dynamic specifications (Panel A of Table 5) to some extent accounts for delayed responses. Yet, the full impact of tax reforms might conceivably take even longer. Fig. 4 attempts to explore this possibility. We trace pre- and post-reform evolutions of our preferred proxy for the tax base (measure $\mathrm{D}$ ) for the five cantons that have adopted AITR cuts of 40 percentage points or more, and for which we have at least 4 years of observations before and after the reform. We plot residuals from a regression of log federal income tax revenue from high-income retirees on canton and year fixed effects against the number of years prior and subsequent to the year of the reform. We do not detect any evidence of increases in the tax base even beyond 4 years after adoption of the reforms. However, due to the small number of observations as well as the possibility of other confounding effects over such long time horizons, this evidence can be considered suggestive at best.

Long delays are even more likely between bequest tax reforms and any migration-induced effects on bequest tax revenues, because it is only at the time of taxpayers' death that bequest taxes are paid (abstracting from gift taxes). In order to shed light on this, Fig. 5 repeats the illustrative exercise of Fig. 4, but reporting bequest tax revenues instead of our proxy for the bequest tax base on the vertical axis. ${ }^{24}$ The graph suggests that cutting bequest tax rates implied commensurate reductions on bequest tax revenues even up to 20 years subsequent to those reforms.

\section{Concluding discussion}

We show that, in official political debates, tax competition provided the principal argument motivating a recent wave of cuts in bequest tax burdens across Swiss cantons. However, we find these cuts to have had little discernible impact on migration patterns of elderly taxpayers overall nor on the tax base represented by these individuals in terms of federal income taxes. We find some evidence of cuts in bequest taxes

\footnotetext{
24 Since we have cantonal bequest tax revenues at annual frequency and up to 2010, Fig. 5 contains more observations than Fig. 4.
} 


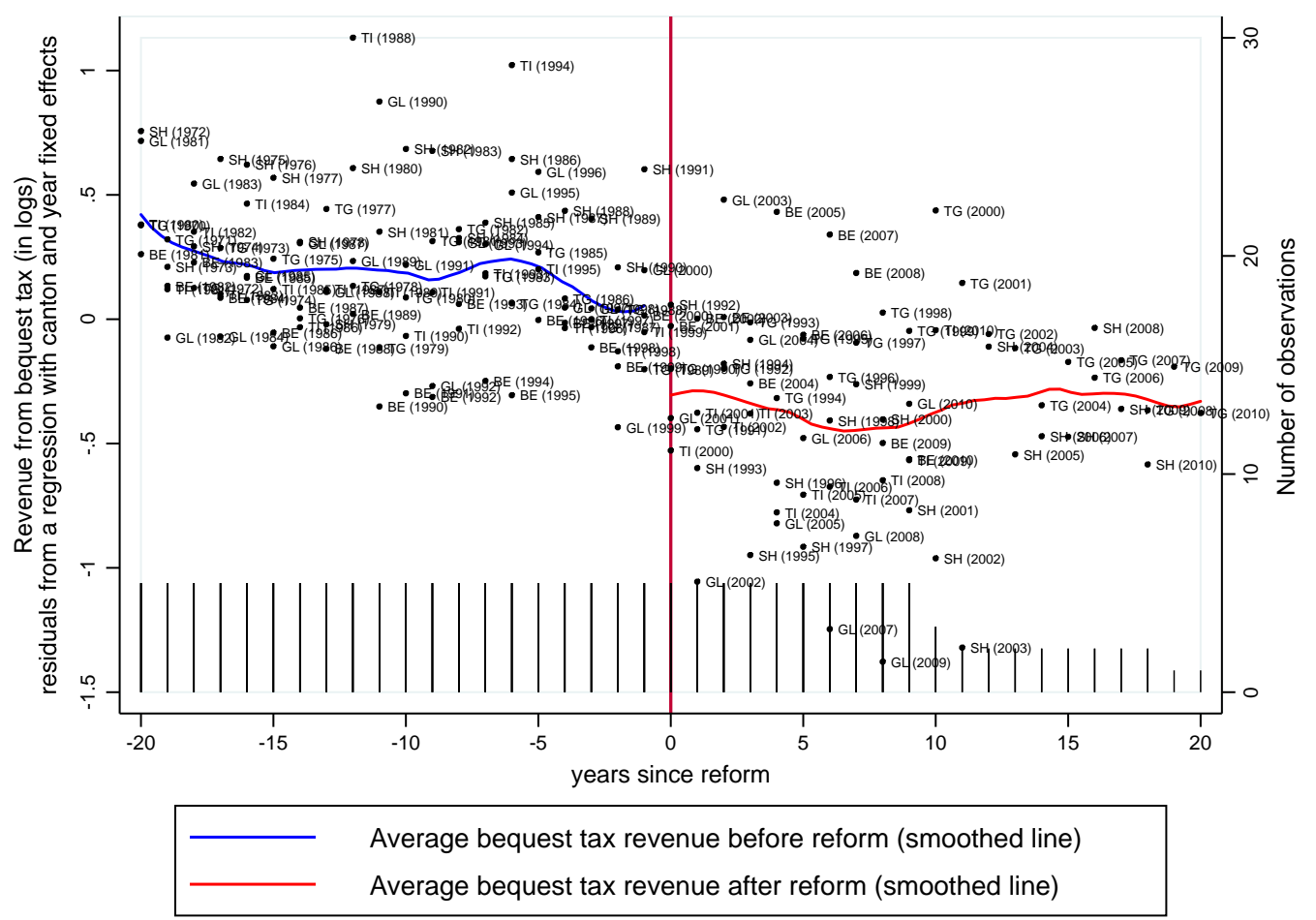

Note: Points are residuals from a regression of bequest tax revenue (in logs) on canton and year fixed effects in the five cantons with the largest tax cuts ( $\geq 40 \%$ of the AITR) occuring at least four years after the start and four years before the end of our sample period. Lines are obtained through Epanechnikov kernel-weighted local polynomial smoothing of degree one. Spikes above the horizontal axis represent the number of observations.

Fig. 5. Long-term effect of bequest tax reforms on bequest tax revenue.

changing the composition of the retiree population in favour of highincome retirees, but these compositional changes are not important enough to translate into statistically significant effects on the overall size of the affected tax base. These results are consistent with existing research on the mobility effects of bequest taxes, where despite evidence of statistically significant migration effects for the wealthiest elderly by Bakija and Slemrod (2004), no significant effects are found for elderly migration overall (Conway and Rork, 2006, 2012).

While the within-sample variation in tax rates did not, on average, cause measurable tax-base responses, our estimations suggest that stronger migration responses by wealthy retirees could be triggered if tax rates were higher. Consistent with this, we find that tax increases yielded significantly stronger tax-base responses than tax cuts. The implied average effective tax rate above which the tax-base elasticity could conceivably surpass unity equals $8.4 \%$ in our preferred specification. This estimated threshold rate, while lying above our sample maximum of $8.2 \%$, may be lower than applied bequest tax rates in some countries. Our results also suggest that, in smaller jurisdictions, optimal bequest tax rates will be lower than the 50-60\% range found by Piketty and Saez (2013) based on national-level bequest-tax elasticity estimates for France and the United States.

Given that observed tax rates are found to have been uniformly below the revenue-maximising level, it appears puzzling that tax competition was invoked so prominently by Swiss sub-national governments. There are nevertheless reasons why one might consider successive cantonal bequest tax reforms to have been optimal responses to changed economic circumstances.

One explanation could be that the wave of reforms represented a common but unequally timed response to a general increase on the mobility of the relevant tax base. Mirrlees (1982), for instance, has shown that the optimal average rate of redistributive income taxation is positively related to the costs of emigration. This mechanism, however, appears to be an unlikely explanation for the erosion of bequest taxes across Swiss cantons. Fig. 3 shows that migration rates of elderly taxpayers were stable over our sample period. This mirrors recent evidence for the United States, for which Wolf and Longino (2005) and Conway and Rork (2010) report remarkably stable interstate migration rates of the elderly over the last six decades. It is noteworthy also that none of the official referendum brochures invoked increased mobility of the tax base as an argument for lowering bequest taxes.

Another explanation could be a shift in political power towards the top of the income distribution. This is the reason for the decline in US bequest tax rates conjectured by Piketty and Saez (2013), but it is a less plausible explanation in the Swiss case, where top income shares have remained stable in recent decades.

Despite the rich panel variation in local bequest tax rates offered by our dataset, our estimations mostly fail to uncover evidence of statistically significant within-sample behavioural responses. Nonetheless, our test could lack power. We are constrained to work with canton-aggregate data, which may not be fine-grained enough to allow us to detect taxinduced avoidance strategies in their entirety. Moreover, aggregation across heir classes could mask heterogeneous revenue elasticities, whereby tax cuts could have positive revenue effects for some bequest types but not for others. The possibility of type II and aggregation errors notwithstanding, our results are suggestive of inelastic bequest tax bases even across small jurisdictions such as Swiss cantons. We are thus still left with the question about the fundamental drivers of recent changes in bequest taxation. Did policy makers simply overestimate the elasticity of their tax bases? Was tax competition invoked misleadingly to cover for other political motivations? Or are there significant economic effects from bequest-tax reform other than the effects on tax revenue? The case of the disappearing bequest tax remains unsolved. 


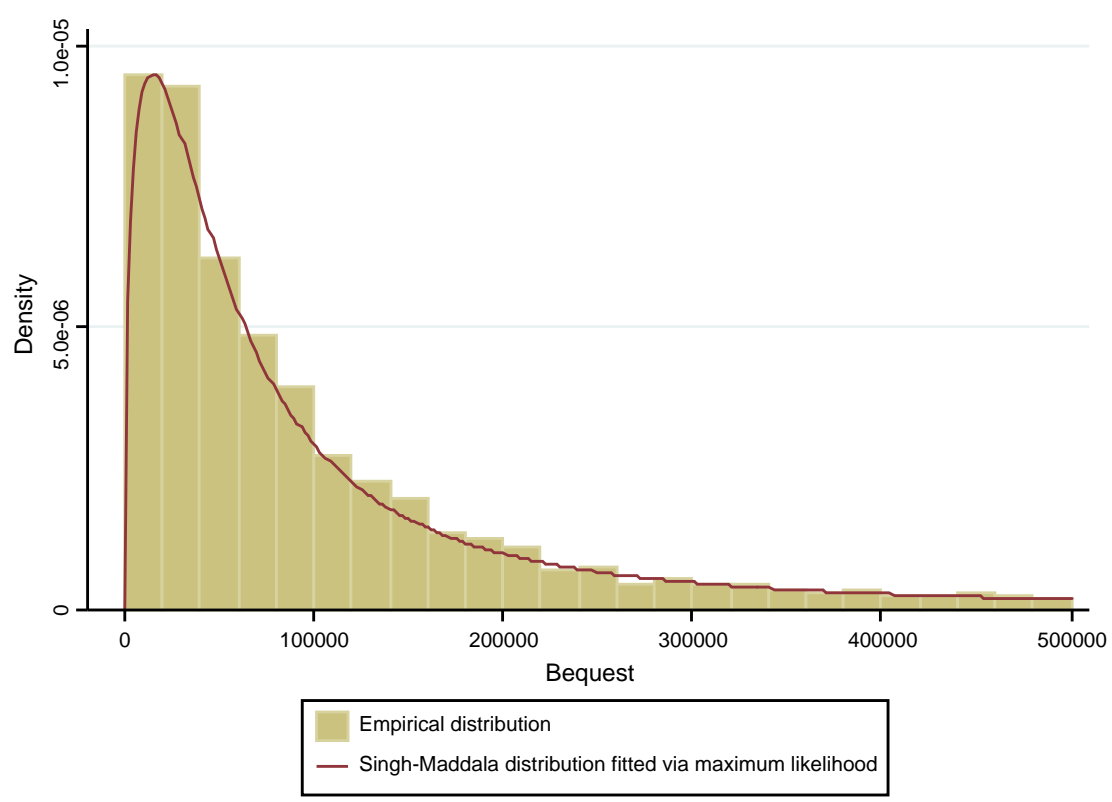

Note: Size distribution of inheritances of all heirs.

Appendix Fig. 1. Size distribution of inheritances in the canton of Vaud, 2002.

\section{Appendix A. The construction of the AITR}

In this appendix, we first present the general methodology behind the construction of the AITR in the cantons that levy inheritance taxes. Then, we explain our strategy to deal with the cantons that tax estates rather than inheritances.

\section{A.1. Inheritance taxes}

In 22 cantons, bequest taxes are due by the heirs at a rate depending on the degree of kinship with the deceased and on the inherited amount. For these cantons, official statistics published by the Swiss Federal Tax Administration ("Charge fiscale en Suisse") report average tax rates levied on six heir types: spouses, direct descendants, siblings, uncles/aunts, nephews/nieces, and other heirs, for inheritances of CHF $20,000,50,000,100,000$ and $500,000 .^{25}$ The published tax rates are defined as the ratio of the tax liability to the amount inherited, and thus also reflect differences among cantons in terms of deductions and exemptions. We construct our AITR measure as a weighted average of these rates, where we weight the 24 different combinations of heir types and inheritance size by the frequency of observed inheritances in each cell.

To compute these frequencies, we draw on a dataset of all inheritances in the canton of Vaud in the period from March 2002 to February 2003 obtained for the purpose of this study. Comparable data for the whole of Switzerland do not exist. The canton of Vaud is the third largest canton and appears to be representative: aggregate frequencies of inheritances across categories of heirs are comparable to those presented by Stutz et al. (2007) for Zürich, the largest canton.

Based on these data, we construct frequencies as follows. We first fit continuous distributions across inheritance sizes for each heir type. We find the discrete distributions to be well approximated by a SinghMaddala distribution (see Appendix Fig. 1). Based on these estimated

\footnotetext{
25 In the cantons of Luzern, Fribourg, Graubünden and Vaud, municipalities may also tax bequests, either with their own schedule or by applying a multiplier on the cantonal tax rate. Official statistics list corresponding inheritance tax rates for the capital town in the four cantons. We add these rates to the cantonal rate.
}

distributions, we compute the frequencies of inheritances for each heir type between the midpoints of inheritance sizes for which tax rates are published. For each sample year, these bounds are computed in 2002 prices using the consumer price index published by the Swiss Federal Statistical Office. Second, we weight these size frequencies by the (time invariant) bequest frequencies across heir type (see the second column of Appendix Table 1). Finally, we apply the resulting sizetype weights to our 24 combinations of official average tax rates in each canton and tax periods.

\section{A.2. Estate taxes}

Three cantons, Graubünden, Solothurn and Neuchâtel (until 2003), levy an estate tax computed on the total bequeathed sum. In Graubünden, the estate tax is raised instead of the inheritance tax, while in Solothurn and Neuchâtel it is levied as a complement. In order to obtain comparable AITR measures for these three cantons, we infer an inheritance-tax equivalent from the statistics of the Swiss Federal Tax Administration that report average estate tax rates levied on estates of CHF 10,000, 20,000, 50,000, 100,000, 200,000, 500,000 and $1,000,000$. For each size class, we impute the amount inherited by each heir type according to the following scenario. We assume these estates to be shared between a surviving spouse, two children, one sibling, two uncles/aunts, two nephews/nieces and one other heir. We assume also that the surviving spouse and the two direct descendants receive at least their minimum legal share, that is $1 / 4$ of the total estate for

Appendix Table 1

Distribution of total inheritances by heir type in the canton of Vaud, 2002-2003.

\begin{tabular}{lrrrr}
\hline & \multicolumn{2}{l}{$\begin{array}{l}\text { Number of } \\
\text { inheritances }\end{array}$} & \multicolumn{2}{l}{$\begin{array}{l}\text { Inherited sum } \\
\text { (in m of CHF) }\end{array}$} \\
\hline Spouse & 1263 & $(16.68 \%)$ & 389.768 & $(16.96 \%)$ \\
Direct descendant & 4663 & $(61.57 \%)$ & 1540.358 & $(67.04 \%)$ \\
Siblings & 541 & $(7.14 \%)$ & 97.114 & $(4.23 \%)$ \\
Uncle/aunt, nephew/niece & 675 & $(8.91 \%)$ & 167.974 & $(7.31 \%)$ \\
Other heir & 431 & $(5.69 \%)$ & 102.400 & $(4.46 \%)$ \\
Total & 7573 & & 2297.614 & \\
\hline
\end{tabular}

Source: Statistical office of the canton of Vaud. 
the surviving spouse and $3 / 8$ for the two direct descendants. The remaining $3 / 8$ are shared among all heirs (including the surviving spouse and direct descendants) according to the observed distribution of total estates computed from the statistics of the canton of Vaud and listed in the last column of Appendix Table 1.

The six estimated heir-type shares are: $31.36 \%$ for the surviving spouse, $31.32 \%$ for each direct descendant, $1.59 \%$ for the sibling, $0.69 \%$ for each uncle/aunt, $0.69 \%$ for each nephew/niece, and $1.67 \%$ for the other heir. Based on these numbers and on the published average tax rates levied on the seven different estate sizes, we approximate by linear interpolation the AITR that would apply on inheritances of $\mathrm{CHF}$ $20,000,50,000,100,000$ and 500,000. For example, a direct descendant receiving an inheritance of CHF 100,000 corresponds to an estate of CHF $100,000 / 0.31=319,285$. This lies between CHF 200,000 and 500,000 , which are taxed respectively at $1.9 \%$ and $3.9 \%$ in the canton of Graubünden in 2000. By linear interpolation, we approximate the average inheritance tax rate in the canton of Graubünden in 2000 levied on a direct descendant receiving an inheritance of CHF 100,000 to be $2.7 \%$.

\section{References}

Bakija, Jon, Slemrod, Joel, 2004. Do the rich flee from high state taxes? Evidence from Federal Estate Tax Returns. NBER Working Paper \#10645.

Bertocchi, Graziella, 2011. The vanishing bequest tax: The comparative evolution of bequest taxation in historical perspective. Econ. Polit. 23 (1), 107-131.

Brett, Craig, Pinkse, Joris, 2000. The determinants of municipal tax rates in British Columbia. Can. J. Econ. 33 (3), 695-714.

Brueckner, Jan K., 2003. Strategic interaction among governments: An overview of empirical studies. Int. Reg. Sci. Rev. 26 (2), 175-188.

Brülhart, Marius, Jametti, Mario, 2006. Vertical versus horizontal tax externalities: an empirical test. J. Public Econ. 90 (10), 2027-2062.

Bucovetsky, Sam, 1991. Asymmetric tax competition. J. Urban Econ. 30 (2), 167-181.

Buettner, Thiess, 2003. Tax base effects and fiscal externalities of local capital taxation: evidence from a panel of German jurisdictions. J. Urban Econ. 54 (1), 110-128.

Cameron, Colin A., Gelbach, Jonah B., Miller, Douglas L., 2011. Robust inference with multiway clustering. J. Bus. Econ. Stat. 29 (2), 238-249.

Conway, Karen S., Rork, Jonathan C., 2004. Diagnosis murder: the death of state death taxes. Econ. Inq. 42 (4), 537-559.
Conway, Karen S., Rork, Jonathan C., 2006. State "death" taxes and elderly migration: the chicken or the egg? Natl. Tax J. 59 (1), 97-128.

Conway, Karen S., Rork, Jonathan C., 2010. "Going with the flow" - a comparison of interstate elderly migration during 1970-2000 using the (I)PUMS versus full census data. J. Gerontol. Soc. Sci. 65B (6), 767-771.

Conway, Karen S., Rork, Jonathan C., 2012. No country for old men (or women): do state tax policies drive away the elderly? Natl. Tax J. 65 (2), 313-356.

Cremer, Helmuth, Pestieau, Pierre, 2006. Wealth transfer taxation: a survey of the theoretical literature. In: Kolm, S., Ythier, J.M. (Eds.), Handbook on the Economics of Giving, Reciprocity and Altruism, vol. 2. Elsevier.

Davidson, Russell, MacKinnon, James G., 2004. Econometric Theory and Methods. Oxford University Press.

de Mooij, Ruud A., Vrijburg, Hendrik, 2012. Tax rates as strategic substitutes. Tinbergen Institute Discussion Paper (2012-104/VI).

Gale, William G., Slemrod, Joel, 2001. Overview. In: Gale, W.G., Hines, J.R., Slemrod, J. (Eds.), Rethinking Estate and Gift Taxation. Brookings Institution.

Graez, Michael J., Shapiro, Ian, 2005. Death by a Thousand Cuts: The Fight Over Taxing Inherited Wealth. Princeton University Press.

Griffith, Rachel, Klemm, Alexander, 2004. What has been the tax competition experience of the last 20 years? Tax Notes Int. 34 (13), 1299-1314.

Haufler, Andreas, 2001. Taxation in a Global Economy. Cambridge University Press.

Hines, James R., 2007. Corporate taxation and international competition. In: Auerbach, A.J., Hines, J.R., Slemrod, J. (Eds.), Taxing Corporate Income in the 21st Century. Cambridge University Press.

Koethenbuerger, Marko, 2011. How do local governments decide on public policy in fiscal federalism? Tax vs. expenditure optimization. J. Public Econ. 95 (11-12), 1516-1522.

Kopczuk, Wojciech, 2010. Economics of estate taxation: a brief review of theory and evidence. NBER Working Paper \#15741.

Mirrlees, James A., 1982. Migration and optimal income taxes. J. Public Econ. 18 (3), 319-341.

Nickell, Stephen J., 1981. Biases in dynamic models with fixed effects. Econometrica 49 (6), 1417-1426.

Parchet, Raphaël, 2013. Are Local Tax Rates Strategic Complements or Strategic Substitutes? Mimeo, University of Lugano.

Piketty, Thomas, Saez, Emmanuel, 2013. A theory of optimal inheritance taxation Econometrica 81 (5), 1851-1886.

Stutz, Heidi, Bauer, Tobias, Schmugge, Susanne, 2007. Erben in der Schweiz. Eine Familiensache mit volkswirtschaftlichen Folgen. Verlag Ruegger.

Wildasin, David E., 1991. Some rudimentary ‘duopolity’ theory. Reg. Sci. Urban Econ. 21 (3), 393-421.

Wilson, John D., 1991. Tax competition with interregional differences in factor endowments. Reg. Sci. Urban Econ. 21 (3), 423-451.

Wilson, John D., 1999. Theories of tax competition. Natl. Tax J. 52 (2), 269-304.

Wolf, Douglas A., Longino, Charles F., 2005. Our 'increasingly mobile society'? The curious persistence of a false belief. Gerontologist 45, 5-11. 